Etnográfica

Revista do Centro em Rede de Investigação em

Antropologia

vol. $23(2) \mid 2019$

Vol. $23(2)$

\title{
A vida na cidade e a invenção da "cultura": imagens de desenvolvimento a partir da "roça"
}

Living in town and the invention of "culture": development images designed from the countryside

\section{Gustavo Meyer}

\section{(2) OpenEdition}

\section{Journals}

Edição electrónica

URL: https://journals.openedition.org/etnografica/6810

DOI: 10.4000/etnografica.6810

ISSN: 2182-2891

\section{Editora}

Centro em Rede de Investigação em Antropologia

\section{Edição impressa}

Data de publição: 1 junho 2019

Paginação: 359-390

ISSN: 0873-6561

\section{Refêrencia eletrónica}

Gustavo Meyer, «A vida na cidade e a invenção da "cultura": imagens de desenvolvimento a partir da "roça"», Etnográfica [Online], vol. 23 (2) | 2019, posto online no dia 25 junho 2019, consultado o 21 janeiro 2022. URL: http://journals.openedition.org/etnografica/6810 ; DOI: https://doi.org/10.4000/ etnografica.6810

\section{(c) (;) (9)}

Etnográfica is licensed under a Creative Commons Attribution-NonCommercial 4.0 International License. 


\section{A vida na cidade \\ e a invenção da "cultura": imagens de desenvolvimento a partir da "roça"}

\section{Gustavo Meyer}

A partir da história de vida de cinco egressos da "roça", hoje residentes na sede municipal de Arinos (MG), analisa-se como memórias, signos e experiências tidas na transição à cidade operam em processos de (re)construção identitária que fazem frente à imagem pejorativa lançada sobre a origem e os modos de vida dos "da roça". Em paralelo, a invenção da "cultura", decorrente da recente circulação de valores positivos acerca de tradições populares, dentre as quais as "da roça", marca a configuração de um campo artístico-cultural no qual grupos locais, ligados a uma rede de atores contestatórios, participam na tessitura de imagens que concorrem com uma ideia hegemônica de desenvolvimento.

PALAVRAS-CHAVE: identidade, antropologia do desenvolvimento, rural, história de vida.

Living in town and the invention of "culture": development images designed from the countryside - Based on the life histories of five people who left the countryside to live in the municipal town of Arinos (MG), we analyze how memories, signs and experiences of the transition to the city operate in processes of identity (re)construction that challenge the pejorative image cast on the origin and ways of life of countryside people. In parallel, the invention of "culture," resulting from the recent circulation of positive values associated to folk traditions, including rural ones, marks the configuration of an artistic-cultural field in which local groups linked to a contesting actors network participate in the designing of images that compete with a hegemonic idea of development.

KEYWORDS: identity, anthropology of development, rural, life history.

MEYER, Gustavo (meyer_gustavo@yahoo.com.br) - Instituto de Ciências Agrárias, Universidade Federal dos Vales do Jequitinhonha e Mucuri, Brasil. 


\section{INTRODUÇÃO}

As transformações recentes do trabalho e da vida cotidiana no território que circunda a pequena cidade de Arinos, no noroeste de Minas Gerais, podem ser vistas como associadas ao modelo de desenvolvimento que ali se desdobrou. Por um lado, esse modelo foi fruto de escolhas políticas de ordem macro realizadas décadas antes (Fausto 2006; Delgado 2005); por outro, foi posto em ação como consequência de uma modernidade inspirada na ordem capitalista e nas novas tecnologias. Esta é uma visão genérica e o redirecionamento das lentes investigativas à vida de agentes sociais locais desvela processos particulares que se deram no "encerramento" de uma "época das fazendas" e no aparecimento de "firmas", de monoculturas "gaúchas" e de fazendas capitalistas de cunho empresarial. Nesse processo, marcadamente, a vida na "roça" foi, em grande medida, deslocada às capitais e às pequenas sedes municipais, em alguns casos dando mesmo origem a estas últimas.

Algumas décadas após o grosso desse processo, em 2013-2014, eu realizava nessa região uma etnografia que dava pistas sobre a relação, sui generis e profunda, entre a atividade artístico-cultural de agentes ex-residentes na "roça" e os processos de mudança social ali verificados, nomeadamente de desenvolvimento rural. Danças, folias e outros elementos da cultura da "roça" movimentavam parte expressiva dessa atividade artístico-cultural, que podia agora ser flagrada ocorrendo na cidade, causando algum embaralhamento investigativo, dada a mudança no locus físico de ocorrência. ${ }^{1}$ Este artigo está debruçado sobre essa problemática, a partir da qual tentarei demonstrar como a atual disputa por visões de mundo - por meio da construção de narrativas contrastantes da realidade por atores sociais distintos - tem como lastro a vida outrora vivida na "roça" e as experiências acumuladas por agentes sociais quando das suas transições às pequenas sedes municipais e capitais. As histórias de vida de cinco moradores da sede municipal de Arinos, acessadas entre abril e setembro de 2013 no âmbito de uma etnografia mais ampla realizada na região, iluminam e dão conteúdo empírico à abordagem. No âmbito dessa etnografia, recorri a métodos diversos, dentre eles as observações simples e participante, as entrevistas abertas, semiestruturadas e em profundidade e as conversas informais, cujos conteúdos foram registrados em caderno de campo e complementados com registros fotográficos. Particularmente no que se refere ao que está problematizado no presente artigo, parte substantiva das informações foi gerada por meio do emprego do método das histórias de vida, seguindo as pistas metodológicas de Meneghel (2007), Meneghel et al. (2008), Moreira (2002) e Søndergaard (2002).

1 Entenda-se doravante "cidade" como sendo, em geral, cidade pequena, de pequeno porte, tal qual Arinos (hoje com aproximadamente 18.000 habitantes), de modo a fazer contraste com "capital”, cidade de grande porte. 
Contribuíram com suas histórias, em 2013: Dona Laurinda, "dançadora", "jogadora de verso" e aposentada; Dona Maria, "dançadora”, artesã e aposentada; Seu Antônio Maria, "guia” da dança de São Gonçalo e aposentado; Lauro, "imperador" de Folia de Reis, "guia" de São Gonçalo, artesão e pedreiro; Joaquina, coordenadora do Ponto de Cultura Portal Veredas e professora da rede municipal de ensino. Trata-se de narradores caracterizados pelo trabalho e residência nas "roças" antecedendo a vida na cidade e pela relevante atuação artístico-cultural consubstanciada em apresentações de danças e de folias e em gestão cultural de grupos e processos atuais locais. ${ }^{2}$ Com exceção de Seu Antônio Maria, os nomes citados são fictícios. Na medida do possível, privilegiei a forma nativa de falar e as categorias êmicas recorrendo a aspas, visando possibilitar a apreensão de significados particulares, evidentemente que com limitações. O texto que segue nas próximas seções foi produzido a partir dessas histórias, mesclando-as e distribuindo-as de modo a facilitar ao leitor a montagem mental dos (con)textos vividos. Os focos das narrativas foram, em grande medida, produzidos pelos próprios contadores, apesar de que algumas questões orientadoras foram formuladas com antecedência. Observar-se-á, particularmente em relação às mulheres, a relevância de momentos mais trágicos da vida compondo o eixo orientador das próprias histórias. A despeito disso, sugere-se ao leitor que não reduza a vida desses contadores a um apanhado de momentos trágicos; deve-se ter em conta que a transição às sedes municipais, a qual foi destacada, é que o foi, e não a vida como um todo. Trata-se de histórias que se passaram em grande parte na "roça", "roça" esta substancialmente diferente da de hoje.

As ações artístico-culturais realizadas por esses cinco narradores em Arinos devem ser entendidas ocorrendo por dentro de - ou integradas às - ações de uma rede maior de atores que coloco enquanto "contestatórios", organizados e reconhecidos enquanto sociedade civil ou movimento social. Trata-se de uma rede bastante coesa, cujo discurso valoriza a cultura da "roça" e recorre a uma narrativa literária fundada no escritor João Guimarães Rosa, em processo de retroalimentação da narrativa nativa (Meyer, Marques e Barbosa 2016). A narrativa faz contraponto à ideia hegemônica de desenvolvimento, fundada na "modernização do campo", e é forjada, particularmente, em eventos e processos artístico-culturais emblemáticos na região que circunda e envolve Arinos. Tais eventos, assim como a forma de ação dessa rede contestatória, serão comentados mais adiante. O encontro entre as trajetórias de vida desses narradores e as operações dessa rede - a qual em tempos mais recentes eles vieram a compor - se dá pelo reconhecimento dessas trajetórias por parte dos atores ligados à rede. Há, assim, um compartilhamento dos valores que

2 “Narradores" ou, mais adiante, “contadores”, não constituem referências identitárias, mas designações minhas para referir as cinco pessoas que contribuíram com suas histórias de vida. 
sustentam as histórias de vida nos narradores, valores estes, muitas vezes, conflitantes com aqueles que guiaram a lógica hegemônica de desenvolvimento que se desdobra ali.

Do ponto de vista teórico, a presente pesquisa insere-se na perspectiva de uma socio-antropologia do desenvolvimento, no sentido em que a preposição antecedendo "desenvolvimento" denota menos algum esforço de tentar delimitar uma subdisciplina das ciências sociais e mais o reconhecimento da polissemia conferida pelos atores sociais em relação ao que é desenvolvimento; há, assim, disputas pela representação da realidade e pela produção de sentidos relacionados ao desenvolvimento. ${ }^{3}$ Ao invés de enxergar o desenvolvimento de forma totalitária, busca-se reconhecer e direcionar o olhar investigativo à forma como os atores locais acessam signos e práticas da modernidade e os atualizam em seus mundos sociais, muitas vezes repaginando-os (Arce e Long 2000). Em outros termos, trato do encontro entre a visão ocidental e a operação de outros repertórios culturais, ou, de outro modo, lanço luz à assunção de que a modernidade implica em contratendências e ressignificações. Estas, ainda que guiadas também segundo interesses particulares, são formuladas no bojo da cultura e das experiências de vida; a mudança contemporânea, então, é reconhecidamente complexa, heterogênea, multifacetada, sem que seja possível assegurar algum sentido teleológico. Evidentemente, esse posicionamento acerca do desenvolvimento (rural) contrasta, entretanto, com algumas interpretações clássicas das ciências sociais relacionadas à movimentação de pessoas entre a "roça" e a cidade.

Uma das interpretações sobre a transição recente às cidades é aquela a partir da qual se busca posicionar os novos habitantes destas últimas em situação de maior ou menor nível de constrangimento ou de liberdade. Nessa perspectiva, podemos encontrar variações teóricas, desde uma ótica funcional-estruturalista (Durkheim 2015) - na qual se pressupõe a existência, nas cidades, de indivíduos mais autônomos e elevado grau de solidariedade orgânica - até um ponto de vista formista/construcionista e interacionista, como assumiam respectivamente Simmel (2006) e Goffman (1989); nestas últimas perspectivas, é assumida uma maior liberdade no mundo urbano, contrariamente a determinados regramentos, que estariam implícitos na vida rural. Numa segunda interpretação clássica, o foco estaria direcionado a evidenciar, nessas transições às cidades, processos de racionalização e burocratização, na perspectiva de Weber (1994, 1987), ou de alteração de relações de dominação quando ascende uma classe burguesa, substituindo uma elite agrária tradicional. Ainda numa terceira visão - que denota um ponto de vista marxista -, a nova vida na cidade

3 Trata-se de um reconhecimento similar àquele que decorre do emprego do termo antropologia da política, ao invés de antropologia política, ou seja, de que o sentido de política é determinado socialmente nos diferentes contextos (cf. Peirano 1997). 
daria margem à intensificação da divisão social do trabalho e à complexificação da sociedade, fazendo surgir um contingente populacional desenraizado, explorado e moralmente empobrecido. Em qualquer uma dessas interpretações, o movimento gradativo de migração às cidades, mesmo que com trânsitos à "roça", nos sugere a decomposição do campesinato, como efeito "da modernidade", representada, por exemplo, pela mecanização agrícola. Algo similar poderia ser apreendido, também, das correntes teóricas liberais. Num sentido oposto, entretanto, a observância dos trânsitos entre a "roça" e as cidades, particularmente os seguidos retornos à primeira, remonta àquela visão chayanoviana de que há sempre um processo de adaptação e resistência detrás dessa movimentação, na direção de, invariavelmente, se manter os modos de vida camponeses ou rurais (cf. Carvalho 2014).

Esses pontos de vista teóricos, de modo geral, pressupõem forte dicotomia entre rural e urbano e remontam aos esforços analíticos de Ferdinand Tönnies (1957), quando este esboça uma diferenciação entre comunidade (a "roça", no nosso caso), marcada pelo "interconhecimento e pela afectividade, pelos contatos personalizados e pelas relações primárias face a face" (Silva 2012: 216), e a sociedade, por sua vez caracterizada pelas "relações transitórias e impessoais, segmentarizadas e contratuais” (Silva 2012: 216). Seja Tönnies ou qualquer um de uma lista extensa de autores reconhecidos nas ciências sociais (cf. Silva 2012: 216-222), encerram por construir uma dicotomia entre urbano e rural que, ora sugere a expansão do primeiro em detrimento do segundo, ora um processo de resistência de classes camponesas e seus modos rurais de vida, considerados como autênticos. De forma distinta, no presente estudo, afastamo-nos desse cunho teórico-estruturante, ou das metanarrativas, ou das tendências homogeneizantes que estariam implícitas na movimentação entre "roça" e cidade. Não exatamente na direção de negar em absoluto a existência de tendências de ordem macro e seu poder estruturante, mas na de reconhecer, sobretudo, a diversidade de possibilidades que os atores sociais podem revelar em relação à mudança social e cultural quando residindo em um "novo" espaço.

Busco lançar luzes à contestação e às tentativas dos atores diversos de construir imagens, discursos e práticas, num processo de atribuição de significado ao rural, ou melhor, ao desenvolvimento rural, acionando representações marginais da história. Esse processo, como veremos, exige o reposicionamento constante de atores, gerando interfaces sociais e epistêmicas, nomeadamente, interfaces de desenvolvimento (Long 2007). Assumem-se os interesses e as coalizões em cena, como aquela expressa pela rede à qual os contadores de histórias de vida estão ligados. Nesse sentido, a "persistência camponesa" é expressa muito mais no âmbito da (re)construção identitária e da reflexividade, em um mundo cheio de incertezas, ansiedades e novos signos. O modelo ocidental de desenvolvimento (racional, legal, burocrático e produtivista) cria, 
com tensão e conflito, subalternos (Escobar 2005), mas não sem capacidade de reposicionamento, inclusive dos conteúdos modernos, em processos de mudança social. Nestes, não raro há a construção de margem de manobra, pelo recurso à cultura, à imaginação (Arce e Long 2000) e ao estabelecimento de conexões. Também, observa-se a produção de imagens e narrativas de desenvolvimento dando significado à vida das pessoas.

\section{A VIDA NA “ROÇA” MEMORADA}

O tempo vivido na "roça" é ora lembrado como tempo difícil, de escassez e "dificulidades", ora tido como tempo de saúde e harmonia entre vizinhos e parentes. Na memória, a "roça" apresenta-se como local ainda "pré-moderno", desprovido de energia elétrica, onde se lava roupa no rio, se põe sela no cavalo para locomoção, se faz óleo de mamona para queimar em candeias, se fia para fazer roupas. Lá na "roça" passada, mas vivida, as informalidades civis tomavam o espaço do documento, da certidão de nascimento; extremas eram as dificuldades de locomoção para as cidades. A "roça" é memorada, sobretudo pelos mais velhos, pelas escolas rígidas, da palmatória e dos "argumentos". ${ }^{4}$ Mas não por escolas em abundância, pelo contrário: em contexto onde quase tudo se aprendia com os pais, a escola era tida como coisa para poucos, e a aplicação de castigos nesse espaço era prerrogativa de alguns. Escola na "roça" era quase nunca "arte" para meninas. Fazendeiros, sendo "chegados" ou não, podiam prover o ensino "público", a escola, dando vazão àquela famosa indistinção entre o público e o privado (Martins 1994). Eram os mesmos fazendeiros de quem se compravam alimentos em situação eventual, geralmente em troca de trabalho.

A "prosa" sem tempo - para acabar - e o tempo sem "prosa" compunham o cotidiano dos que ali viviam. Eram as "prosas" para as quais, com o intuito de viabilizá-las, se percorriam distâncias longas: prosas dos amigos, dos "chegados" e parentes (Cerqueira 2010), com quem eram estabelecidas relações de solidariedade e reciprocidade (Sabourin 2009). Apesar das distâncias, a vida comunitária se realizava e era sempre atualizada nas festas, muitas das quais também proporcionadas por fazendeiros: era, em geral, a "época das fazendas", em que se estabeleciam relações de dependências com estes, inclusive da cessão de terras para a moradia e trabalho de "agregados". Ainda assim, é uma época tida como de "liberdade" - expressa em termos de "sentir-se à vontade" -, de se andar sem "perigo", de se mudar com frequência para procurar lugar melhor (terra melhor, "patrão" melhor, parente para apoio, trabalho, enfim...). ${ }^{5}$

4 "Argumento" corresponde a uma competição escolar na qual os alunos dirigiam perguntas uns aos outros no intuito de verificar o conhecimento alheio. Quando a questão não era respondida de modo considerado adequado, o aluno que elaborara a questão podia bater com uma vara no colega.

5 Para adentrar a noção nativa de "liberdade", ver Andriolli (2011). 
A "roça" é memorada como espaço "com mulher", com maiores possibilidades de estabelecimento de relações amorosas (a despeito do atual contexto de masculinização; cf. Weisheimer 2005), espaço para se namorar sem explicitar, para se casar e constituir família extensa (terra de muitos parentes, de ser fácil cuidar das crianças), terra da religião forte e regradora em termos de segurança.

Apesar das relações de ajuda que eram ali estabelecidas, não raro a "roça" era local de se flagrar dificuldade na alimentação; terra também de fome, porque se vivera a "época das fazendas" e, igualmente, seu declínio. ${ }^{6}$ Logo, a "roça" sempre fora espaço de muitas agruras, de ser comum morrer cedo, porque as intempéries de lá nem sempre recebiam a esperada proteção divina, tampouco remédios e médicos. Estes últimos, havendo-os, eram esparsos e raros. Em ocorrendo mortes, faziam-se roupas de enterro, pelas mulheres, ao passo que se faziam caixões aos mortos, pelos homens, em grupo. A solidariedade e a reciprocidade eram mesmo formas de lidar com a "roça": para a fome, doavam-se alimentos; para os machucados, faziam-se curativos.

Quase tudo o que se precisava na "roça" tinha de ser feito ali mesmo. Iniciava-se pelos itens de vestimenta e alimentação, incluindo a animal. Mandioca era sempre plantada para fazer farinha; cana, para tocar o engenho e fazer rapadura e açúcar, eventualmente cachaça; feijão e milho eram plantados para serem comidos ou trocados por itens essenciais, tais como as ferramentas para o trabalho; do milho cresciam alguns animais. A "roça", para muitos, era terra de feijão; para outros ainda continua sendo. Algum gado próprio, pouco, havia, e se tinha que cuidar para reproduzir e garantir algum leite. Assim, com tudo a se fazer, constituíam-se vidas de trabalho precoce, desde a infância; esta se desdobrava paralela ao ofício de se aprender as coisas que tinham que ser feitas - essa seria a origem de habilidades manuais hoje ressignificadas enquanto "artesanato de tradição". Às crianças não lhes restava tempo muito, que sobrasse às brincadeiras abundantes, tampouco havia recursos para a compra de brinquedos. A "roça” era, então, espaço dos brinquedos feitos à mão, com hastes de folhas de buriti (Mauritia flexuosa) e bonecas feitas de sabugo de milho, vestidas com retalhos costurados com espinhos de tucum (Astrocaryum huaimi). Às crianças ocorria de brincadeira e labor se misturarem: se aprendia a costurar, a fazer "artes".

$\mathrm{Na}$ vida adulta, o trabalho era em boa medida voltado "pra fora", à "empreita", "pro fazendeiro". As vidas de Lauro, de Dona Laurinda (e de seu marido à época) e de Seu Antônio Maria eram fortemente dependentes dos trabalhos ofertados por terceiros: em tempos mais antigos, por fazendeiros, e, mais recentemente, pelas "firmas". E se a oferta de trabalho "mudou de dono", o costume e a necessidade de se fazer quase tudo o que se consumia

6 Em relação a esta época, frisa-se a força e a abrangência da divisão social entre "fazendeiros" e “agregados", na qual os primeiros agiam como provedores e cediam terras aos segundos. 
também foi mudando, aos poucos. A industrialização não chegara na "roça" à "época das fazendas" e "firmas", mas seus produtos lentamente começaram a aparecer, eram percebidos mais disponíveis, algo que ocorria em paralelo à expansão das relações trabalhistas capitalistas (Martins 1991). Assim, a "roça" foi espaço também de se viver transições: viveram-nas todos os narradores de histórias de vida.

A vida de trabalho na "roça" impunha intempéries ao corpo, marcava-o. O mesmo corpo que ficava privado de cuidados médicos e estéticos: em suma, aquele corpo que os denunciava enquanto viventes da "roça" (Bourdieu 2006). O modo de vida dali era, então, calcado no corpo físico, moldado como que em resposta à vida de agruras, "de vida difícil" [Dona Maria]. A "roça" era penosa às mulheres que ora realizavam o trabalho doméstico e cuidavam dos filhos, ora o dividiam com o trabalho da lavoura, particularmente nas frequentes ocasiões em que os maridos saíam em busca de trabalho fora, nas fazendas (principalmente até a década de 1960), nas "firmas" (a partir da década de 1970) ou nas fazendas "modernas" (mais recentemente). O trabalho "pra fora" podia, de outro modo, estar vinculado à feitura do carvão a partir do cerrado, carvão que, na transição, já era demandado por siderúrgicas engajadas no processo de modernização de Minas Gerais e do Brasil.

"Fui morá cos meu minino, trabaiá, daí... eles que tinha dez anos já começo trabaiá também mais eu, na firma, plantando eucalipto, dano combate ni furmiga, intoxiquei [...] e dano combati ni furmiga com veneno. Intoxiquei com veneno, quase eu morro e o neném morre [...] eu trabaiei um dia, e no outro dia eu num guentei não, aí me tiro do combati e pôis eu lá pru vivêro, pra plantá" [Dona Laurinda].

Assim como observou Brandão (1999) no interior paulista, na "roça", homens e mulheres assumiam papéis diferentes. Inclusive, a "roça" é apresentada diferentemente entre homens e mulheres. Se para o homem a "roça" é sinônimo de "dificulidades" por causa do trabalho com os roçados e nas "empreitas" - porque "seria ele" quem acabava por trabalhar pesado -, a mulher, ao representar tais dificuldades, as associa à sobreposição de tarefas múltiplas, dentre as quais as domésticas, e à condição de, muitas vezes, estar subjugada ao marido. Tal condição, no entanto, foi frequentemente relatada a partir de uma imagem naturalizada da condição da mulher ali, como que exercendo um papel: o de mulher da "roça". Desta feita, a "roça" não era espaço, à época, de mulher trabalhar "pra fora", de beijar homens ao cumprimentá-los, de participar de folias e, até, de criticar o marido em ocasiões de adultério descoberto - apesar de que os adultérios aparecem mais associados à vida já nas sedes municipais. Às mulheres, a "roça” se apresenta, em geral, como espaço de vida com marido. 
A situação da mulher na "roça", e na transição para as sedes municipais, é relatada como sendo desprivilegiada. Em parte porque tiveram que enfrentar, na transição, os alcoolismos dos maridos e, frequentemente, maus-tratos e violências domésticas por parte destes, sem direito a reclamação. Daí que os problemas de depressão atuais, identificados e relatados, aparecem vinculados, grosso modo, às mulheres que, com alguma ênfase, acabam por associar "roça" a baixa autoestima. "A gente tinha um sistema que era assim, era um sistema esquisito que a gente tinha. Se a gente fosse aproximar de uma moça e beijasse ela, não servia pra casar com a gente não... era um trem esquisito, era diferente [...] Tinha umas que namorava pelo buraco da parede..." [Antônio Maria]. A condição de mulher na "roça" era experienciada logo nos primeiros anos de adolescência, quando o olhar atento - e a atitude - do pai se revelava. Pai homem - a quem não se contrariava facilmente, dadas as sanções implícitas ao ato. Pai, ou avô, de influenciar casamento para a filha não ficar "encalhada". Marido, homem, de inibir certas experiências de liderança comunitária e de autoafirmação.

As festas e folias eram - e ainda são - eventos sociais marcantes e estabeleciam a ligação entre o mundo do trabalho, o campo da religião e os relacionamentos amorosos e matrimoniais. As "festas de missa" e as "festas de banquete", oferecidas pelos fazendeiros (Souza 2000), complementavam as folias e as "farras" da "roça". Estas últimas podiam marcar momentos de trabalho comunitário, de colheita, de plantio, entre outros. Como as "festas de engenho" que marcavam o trabalho com a cana. Festas em que era possível dançar até o amanhecer: dançar seja o "São Gonçalo", em ocasião de pagar promessa, seja a "caninha verde", o "tamanduá", o "carneiro", o "batuque" ("danças de roda"), o "forró", seja a "catira", o "lundu" e o "quatro" (danças profanas desempenhadas nas folias), entre outras. Tudo isso e muito mais se dançava na "roça", de modo a compor fortemente as vidas memoradas. Foram tempos de folias e danças com rabecas, violas, violóes, pandeiros, cavaquinhos, caixas e muita cantoria. Tempo da zabumba, da sanfona e do triângulo, tempo de "jogar versos"... Em boa medida essas danças podem ser presenciadas ainda hoje na "roça"; entretanto, percebem-se, em geral, alguns deslocamentos, a exemplo das "danças de roda", que parecem não mais ser significadas enquanto momento de paquera.

"As diversão de lá era assim, quando era nessa época de moagem, engenho, eles pegava, juntava duas, três famílias, e trabalhava tipo assim, de uma comunidade, como cê tava falando: todo mundo junto. Aí ia fazer farinha, ia fazer moagem, e ali todo mundo trabaiando junto. A noite era uma festa! [com entusiasmo] [...] Era um trabalho muito bonito. E se tem uma coisa que eu guardei, assim, que a gente ia todo mundo, assim, trabalhava, tinha aquela turma que torrava, tinha a turma que rapava, tinha a turma 
que tirava porvilho, tinha a turma que rancava as mandioca, tinha a turma que ia carrear... [...] Aí quando era noite todo mundo terminava, quando terminava aquilo tudo, aí fazia uma foguêra, aí tinha ali o violão, tinha a sanfona, todo mundo ia dançá, cantá [...] tinha dança de roda... mas eu não participava, que aí já vem a burocracia de um sinhô di idade [seu avô, que a cuidava] que não poderia deixá uma jovem, como dizia ele, 'num era a minha filha' [...], tinha forró. Agora no forró ele deixava dançá [porque o avô podia ficar por perto]" [Joaquina].

Essas danças (principalmente) e "festas de santos", e também as folias, eram ocasiões privilegiadas para que rapazes e moças burlassem a vigília do pai austero. As danças constituíam momentos únicos de o rapaz pegar na mão da moça, e, em eventual interesse de "namoro", apertar sua mão com intensidade exata para estabelecer a paquera. A relação amorosa dita "namoro" podia, então, ser determinada na própria festa, momentos depois da dança, por meio de conversa. Em estabelecido o "namoro", beijo, abraço ou aperto de mão não havia. Daí que, em grande medida, as histórias narradas foram forjadas nas "danças de roda" da "época das fazendas". Dessas rodas derivaram casamentos diversos, assistidos por sanfoneiros que não se furtavam a prover a animação geral da festa. Eram festas onde se bebia menos, a despeito da abrangência do uso do álcool como instrumento de socialização nas festas atuais.

“Os rapaz jogava verso pra gente, pras moça, desafiando a gente, jogava os verso, aí a gente sabia [que eles estavam a fim]. Aí a gente jogava os verso pro rapaz também. Era nos verso e nas dança que a gente conquistava namorado e [eles] conquistava a gente". [Dona Laurinda]

Foi assim que muitos matrimônios foram tecidos e famílias constituídas. Famílias que acabavam por reproduzir as formas de solidariedade, reciprocidade e o modo de vida "livre", árduo e desmaterializado em termos financeiros; que viviam, em geral, no contexto das "fazendas".

Instauravam-se, gradativamente, os tempos modernos, regidos pelo advento das leis trabalhistas e pela desagregação subliminar das pessoas dali, porque a permanência de "agregados" nas terras de fazendeiros deixavam-nos em situação de dívida trabalhista para com os primeiros. Assim, a continuidade na "roça", naquele momento, dificultava-se pela ausência, por parte dos "agregados", dos títulos de posse de terras que, até então, pareciam abundantes. Assim, destaco a relação que há entre “a terra já não tava dando", causa disparadora da evasão apontada, e o rompimento do vínculo com os fazendeiros. A razão que desencadeou a gradativa saída da "roça" não esteve reduzida à mera disponibilidade de terras para a moradia e o roçado, mas envolveu a própria relação de tutela com o fazendeiro e, também, a exigência da abundância 
de terras, porque o gado complementar ao roçado era criado em sistema bastante extensivo, em regime de baixa pluviosidade. Os "roçados", sozinhos, parecem não ter sido suficientes para a sustentação das famílias na "roça", ademais a implantação de monoculturas teria feito ocorrer ali "pragas" antes não vistas nesses roçados. De qualquer forma, as motivações de saída da "roça" e ida para as cidades e capitais, discursivamente, foram diversas.

Segundo Lauro, as mulheres foram todas trabalhar em "Brasília". ${ }^{7}$ Lauro saíra em busca de trabalho com o tio em Brazlândia (vizinha a Brasília); queria, nessa experiência, comprar instrumentos musicais, porque era muito ligado às "farras" em sua comunidade. Dona Maria saíra por conta de doença sua e de um dos filhos, e seu filho, mais adiante, fora a "Brasília" para trabalhar e conseguir comprar um teclado. Dona Laurinda e muitos outros saíram das "roças" porque a família estava passando necessidades, e fome: "Não tinha nem café para tomar!" Seu Antônio Maria saíra da "roça” para garantir estudos aos filhos; afinal ele, à época, tinha fixação por essa ideia. Aproveitou-se da grande enchente de 1979 e fez dela justificativa para iniciar a resolução de uma mudança que lhe parecia latente. À época da saída de Seu Antônio Maria, era forte a circulação de valores positivos acerca das cidades, envolvendo questões educacionais, de saúde e de trabalho, ao passo que, em paralelo, havia sido construída uma imagem pejorativa sobre a vida na "roça", intensamente midiatizada até a década de 1990. "A gente mudou prum lugar chamado Pernambuco, pertinho de Buritis [cidade próxima], roça também, e ficou bem pertinho, porque dizia que era onde tinha serviço, né, e também tinha mais acesso à cidade, pra poder levar minha mãe pra tratar" [Joaquina].

Havia, por parte de muitos, a percepção de uma época transitória. No caso de Seu Antônio Maria, o provimento de estudos aos filhos parece ter ascendido a uma espécie de demanda familiar, à medida que avançou sua percepção acerca da falência de um dado sistema agrário associado a um modo de vida particular, da "roça". Além disso, havia a circulação de valores que taxavam a "roça" e o agricultor como espaço e profissão menores, respectivamente. Esses valores, desdobrados em conjuntura social crítica, pareciam emanar mensagens claras de busca de uma vida melhor em "Brasília" - algo favorecido pelo fato de os destinatários dessas mensagens serem pessoas cujo hábito de se deslocar estava fortemente ligado à cultura, no "movimento" (Andriolli $201 \mathrm{l}$; Cerqueira 2010). No caso dos contadores de histórias de vida, Arinos estava no caminho de Brasília. Em 1980, muitos da "roça" já residiam na sede de pequenos municípios, como Arinos, ou em capitais, como Brasília.

7 "Brasília", aqui escrita entre aspas simples, remete a um conjunto de cidades, ou seja, ao Distrito Federal como um todo, com suas cidades satélites. Brasília, sem aspas, seria apenas uma dessas cidades, a mais rica, de modo que, em geral, quando se fala "Brasília", está se remetendo às cidades satélites em volta de Brasília, tidas como mais pobres. 
"Parece que o sentido da gente é o contrário, em vez de a gente ir pro rumo do entrar do sol, em vez de a gente ir pro rumo do sair [do sol], a gente ia pro rumo do entrar... Parece que a gente achava era assim, se nóis lá pro rumo do Urucuia [vizinha a Arinos], lá nonde a gente morava, pra lá da cidade de Urucuia, se fosse pra gente tocá pra lá pro rumo de São Francisco [oposto a Brasília], parece que tava o contrário, parece que tava indo pro lugar errado, não sei que que era [...] Você pode assuntar que desse pessoal daí, poucos é que mudou pra São Francisco. Não sei se por que é que criou Brasília [eu havia sugerido], eu acho que é por isso. A gente achava que era no rumo de Brasília. Se por acaso aqui não desse certo eu tinha meu pessoal, já morava em Brasília” [Seu Antônio Maria].

\section{CHEGADA À SEDE MUNICIPAL: REPOSICIONAMENTO}

As chegadas à sede municipal de Arinos não constituíram, em geral, tarefas fáceis. Tampouco o foram nas capitais, particularmente, "Brasília". O retorno intermitente à "roça" ou à própria sede de Arinos - no caso de a mudança ter sido realizada para as capitais - passou a ser indicador das dificuldades diversas enfrentadas nos novos espaços de residência. Se nas capitais as dificuldades financeiras eram amenizadas pela disponibilidade real de trabalho, em Arinos, não sendo o trabalho conquista imediata de recursos financeiros suficientes, aos novatos eram impostas condições bastante extremas no que se referia à base material. "A chegada aqui [em Arinos] foi meio cruel, viu, não tinha nem lugar de morar", disse-me Lauro em uma de nossas conversas. Chegara com a família e ficaram na casa de um tio da esposa, provisoriamente. Dona Laurinda e sua família, dada a condição de descapitalização extrema em que se encontravam na "roça", concluíram a primeira mudança para Arinos somente após longa tentativa: tiveram que vender um saco de milho e outro de feijão. Não dispondo de gado que pudessem vender, tal troca significava investimentos expressivos para quem, almejando mudança, se deparava com situação financeira pouco propícia.

Seu Antônio Maria, em relação à mudança para Arinos, disse-me: "Aí nesse tempo eu num fichei. Mas se eu tivesse fichado [conseguido o emprego no Departamento de Estradas de Rodagem de Minas Gerais - DER-MG], nesse ano eu num tinha ficado não, porque eu não conhecia ninguém". A importância, nesse caso, de se conhecer alguém era devida ao fato de o pagamento no DER, naquela época, demorar noventa dias para ser efetuado, a partir da data de ingresso. Em assim sendo, Seu Antônio Maria não teria condições de manter a família durante três meses sem salário, algo que demonstra o elevado grau de descapitalização em que viviam as pessoas da "roça". À época, em geral, não havia dinheiro suficiente sequer para o deslocamento de ônibus até a sede municipal, transporte que podia ser empreendido a cavalo, durante 
alguns dias. Assim, revela-se a importância, e até a centralidade, de se conhecer alguém para um amparo emergencial na sede municipal.

A condição de escassez material extrema em que vivia a maioria das pessoas da "roça" dava margem para que a chegada à sede municipal pudesse soar como um verdadeiro fracasso. Dona Maria, estando já deprimida e com um dos filhos doente, ao ter que enfrentar a mudança com a família, chegou a ser expulsa da casa do pai, em Arinos, tendo que ficar na rua, por não dispor, ali, da rede de ajuda e solidariedade à qual se acostumara na "roça". O resultado, no caso, foi o agravamento de seu quadro depressivo, quadro este que se estendeu por muitos anos. Chegavam os da "roça" muitas vezes sem conhecer ninguém e deparavam-se com condições assaz desfavoráveis ao emprego. No caso de Dona Maria, e outros, a solução imediata foi o trabalho em fazenda próxima, às pressas, o que acabou por lhe garantir residência. Não é sem razão, então, que a chegada de todos os contadores de histórias de vida tenha sido marcada por privações financeiras extremas (ver figuras 1 a 5).

Não preparados para aquela situação - ao que parece, tinham as redes de solidariedade naturalizadas no tempo e no espaço -, enfrentavam os trabalhos considerados piores em um contexto de oferta de trabalhadores relativamente alta, o que pressionava negativamente as remunerações e degradava a condição laboral (esse seria um dos sinônimos do "não haver trabalho", tantas vezes mencionado), em contexto desprovido do acolhimento de amigos e parentes. Muitos, talvez por essa razão, mantiveram vínculos diretos com espaços da "roça" durante muitos anos após a chegada, ainda que residissem "oficialmente" em Arinos. Daí que, na maioria dos casos, fica difícil inferir a residência como tendo sido na "roça" ou na cidade (ver figuras 1 a 4). "Minha vida aqui na cidade foi, foi [...] não é só de rosas não. Não foi fácil não, Gustavo [...]. Muitas coisas que eu não tinha coragem de fazer, depois que eu mudei pra cá que eu fui obrigado a fazer", disse-me Antônio Maria.

A situação da mulher à época, com um papel que nos aparece submisso e sobrecarregado de tarefas, é apresentada nas histórias de vida como sendo mais extrema ainda. A nova vida na cidade impunha rearranjos sociais, econômicos, laborais e psicológicos que muitas vezes produzia alcoólatras: os maridos. Novos sujeitos "cantarolantes" (Dona Maria) e agressivos (Joaquina) com quem as mulheres passavam a ter que lidar, em acréscimo ao conjunto de problemas que já enfrentavam. Ainda, se na "roça" as possibilidades de encontro entre homens casados e outras mulheres eram regradas pelas distâncias físicas, pelo trabalho e pelo jugo moral de parentes e amigos, na sede municipal, em situação comum de não trabalho, tais possibilidades modificaram-se, com "privilégios" aos homens, que geriam financeiramente a família e tinham a prerrogativa de não ter que se justificar às esposas. Em contraposição irônica, o comportamento de ciúme dos maridos, uma vez posicionados na sede municipal, parecia se engrandecer e dotá-los de grande poder viril. Sendo ou não essas 


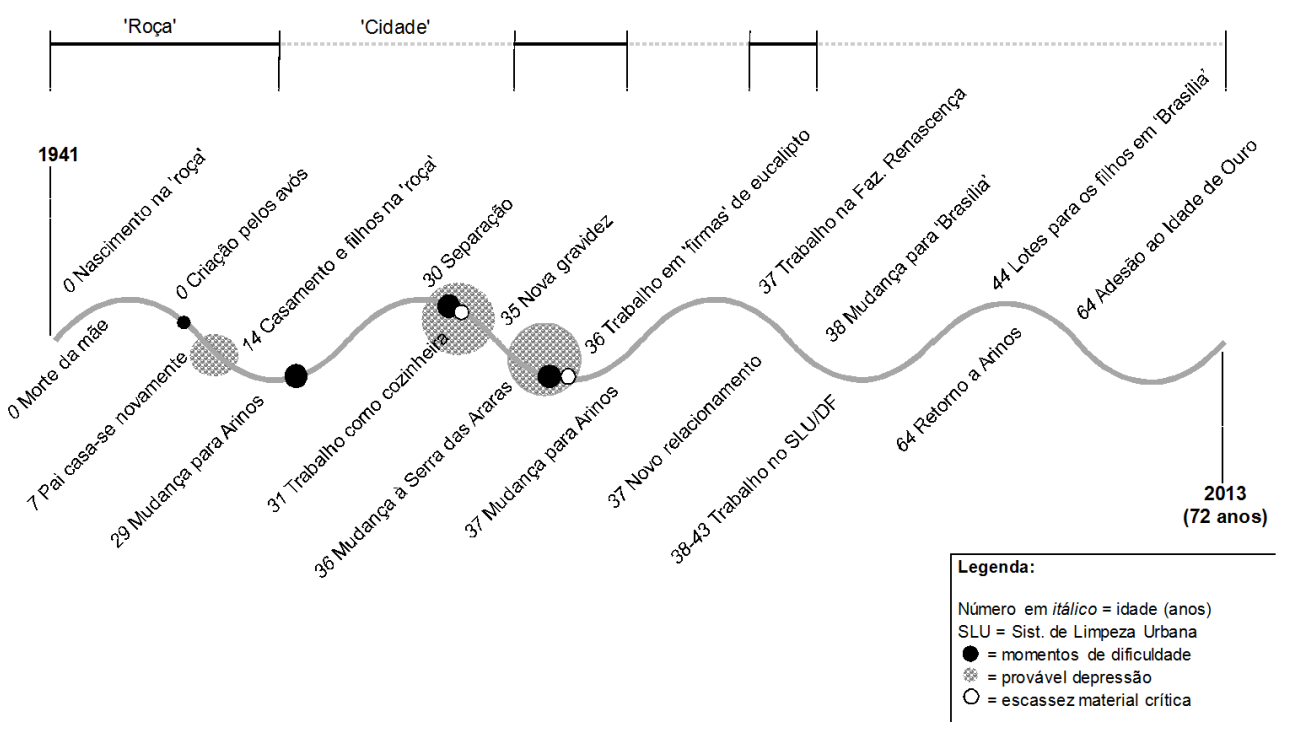

Figura 1 - Linha temporal resumida da história de vida de Dona Laurinda (1941-2013). Fonte: elaborada pelo autor.

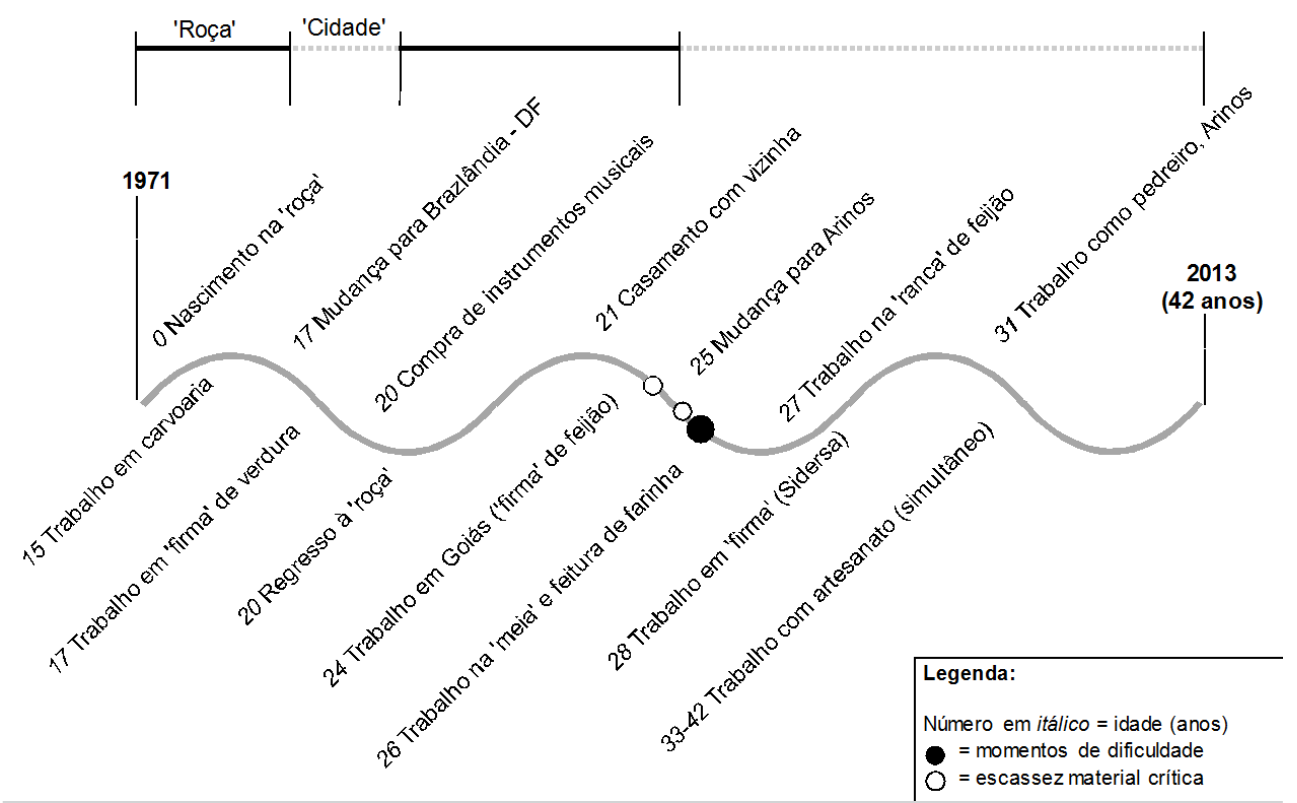

Figura 2 - Linha temporal resumida da história de vida de Lauro (1971-2013). Fonte: elaborada pelo autor. 

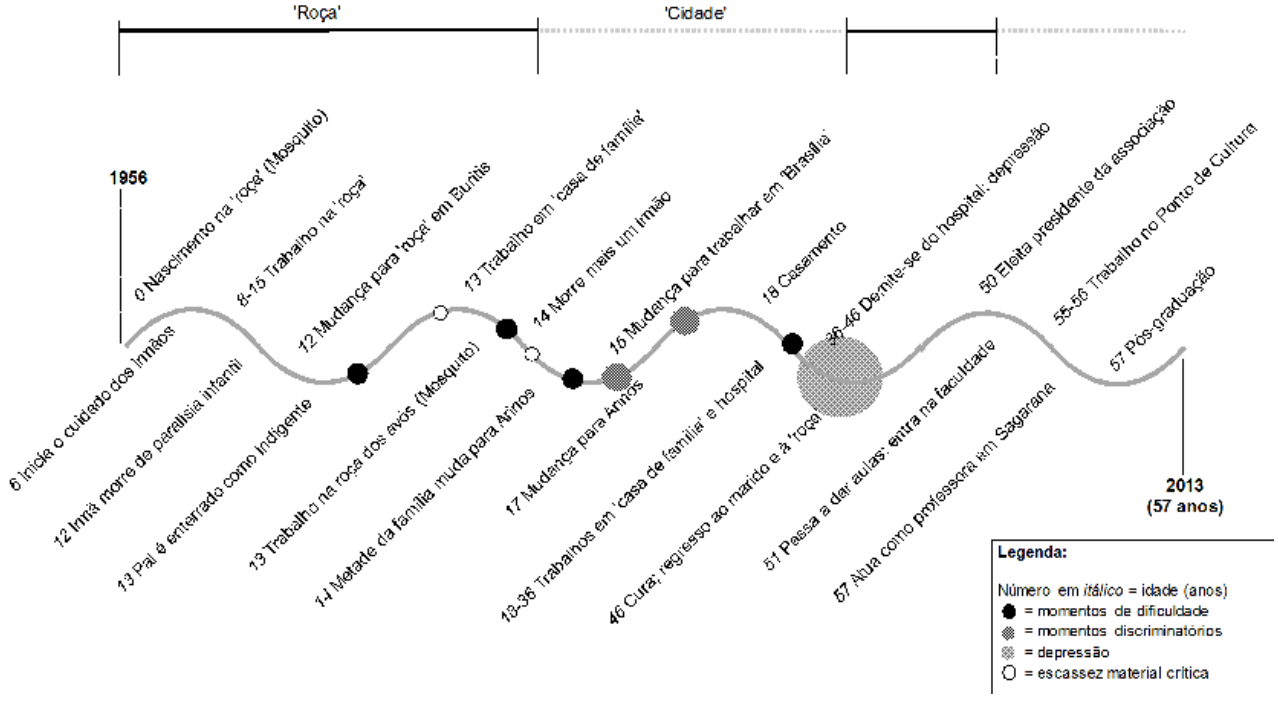

Figura 3 - Linha temporal resumida da história de vida de Joaquina (1956-2013). Fonte: elaborada pelo autor.

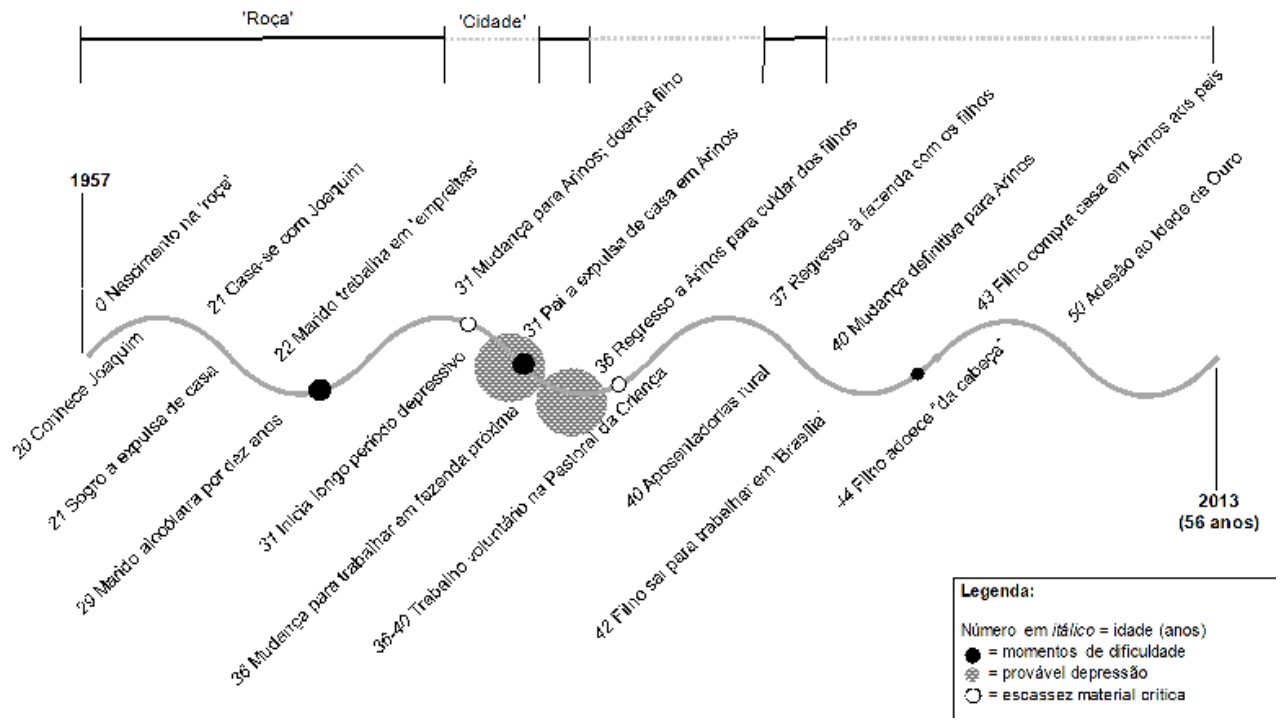

Figura 4 - Linha temporal resumida da história de vida de Dona Maria (1957-2013).

Fonte: elaborada pelo autor. 


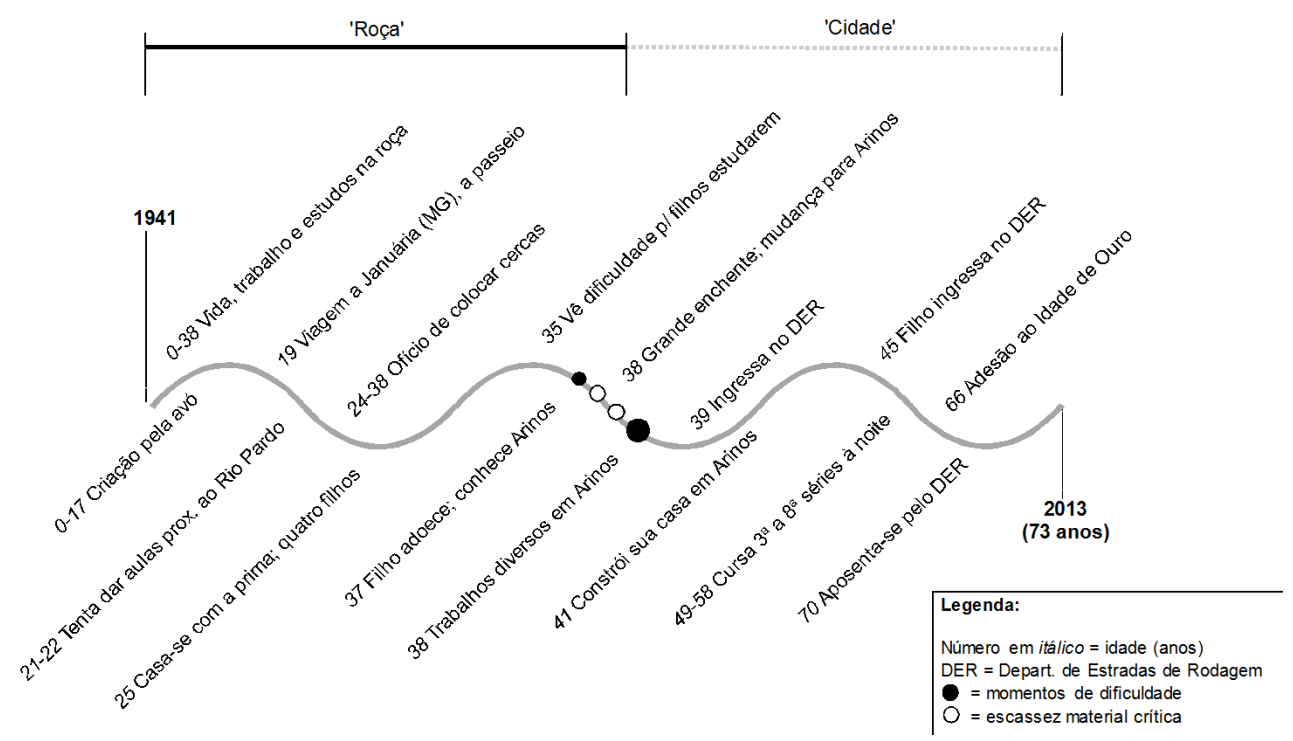

Figura 5 - Linha temporal resumida da história de vida de Seu Antônio Maria (1941-2013). Fonte: elaborada pelo autor.

as razões, coincide que as mulheres experimentaram depressões (figuras 1, 3 e 4) a partir da chegada na sede municipal, às vezes por períodos prolongados. Algumas separações ocorreram, de forma definitiva (figura 1) ou temporária (figura 3), impondo-lhes novos desafios.

"Aí, eu fiquei uns dois, uns dois anos ou foi três anos, cumendo aquelas migarrinha que ele mandava. Se ocê chegasse em casa, chegasse uma visita na minha casa, eu num tinha direito de dar nem um gole de café, porque se cabasse antes do dia que ele marcava nóis ficava aqui sem, que ele não mandava. Era prazo marcado.

Depois fizeram uma coisa lá pra mim [na 'firma' da Serra das Araras] que eu larguei tudo quanto foi sereviço, eu já tava nas esmola, acho que era inverno. Aí meu fio, quando eu vi o povo chegando [...]. Quando eu via uma pessoa chegá lá na porta da frente me chamano, eu curria. Com medo de sê sereviço [querendo dizer que não queria prestar serviços] [...]. 'Gente o que é que tá acontecendo com [Laurindinha] [dizendo que as pessoas falavam dela], porque ela nunca foi de rejeitá sereviço'. No domingo, final de semana, é... todo mundo tava na farra e eu lavando rôpa. E aí, mas não era, mas não era porque eu tava com preguiça, eu tava vendo a estrada de eu passá fome mais meus filho, mas num tinha coragem... de trabaiá [...]. Eu sei que o negócio pra mim foi feio" [Dona Laurinda]. 
Para além das privações e das dificuldades familiares decorrentes da diferença sexual, a vida na cidade grande - em maior grau - e na pequena sede municipal parecia aprisionar a "liberdade" dos "neourbanos". E havia também a questão da sensação de "perigo" que pairava no ar, talvez pelo estranhamento que se colocava aos recém-chegados, a exemplo do bairro Crispim Santana, em Arinos, que abrigava frequências de brigas e alcoolismos até então desconhecidas. O "perigo" das ruas era contraposto à "segurança" do tédio nas casas. Espaço enclausurante sobretudo aos casados, para quem, na cidade, cuidar dos filhos constituía, de modo inédito, tarefa difícil.

Assim, aspectos naturalizados da vida na "roça", mediados pela saudade e agruras enfrentadas na cidade, passaram a ser percebidos diferentemente. Teria sido um processo de "consciência identitária", dado o reconhecimento mais intenso e crônico do modo dos "de fora"? Lauro, por exemplo, antes de constituir família, tentou a vida em Brazlândia. Mas voltava à "roça" intermitentemente, para as "farras" com os amigos, também para tentar um relacionamento amoroso. $\mathrm{Na}$ capital, lembrava-se da "roça", como se as relações de proximidade, vizinhança e interconhecimento lá desenvolvidas - e percebidas "em Brazlândia" - pudessem compensar os regramentos e impedimentos para se estabelecer relacionamentos amorosos. A chegada à sede municipal, dessa forma, não significou a ruptura completa com o modo de viver na "roça". Muitos dos que a deixaram como local de residência, ao se depararem com a vida da cidade, voltaram a ela após curto período. Somente mais adiante é que conseguiram se estabelecer definitivamente (figuras 1 a 4 ).

As próprias pequenas sedes municipais, a exemplo de Arinos, mantiveram - e em algum grau ainda mantêm - traços que remetiam à "roça". A energia elétrica apenas ficou disponível à maioria da população em 1986 (Antônio Maria). Ali mesmo era local de caçar tatu, de aparecerem filhotes de ema perdidos, de abertura de pequenos roçados de feijão ou mandioca. Era local, inclusive, de revisitar antigos esquemas de trabalhos comunitários. A "roça", assim, está um pouco localizada, ainda hoje, dentro da própria sede municipal (Wanderley 2009). Se foi necessário aguardar Seu Antônio Maria chegar da "roça" para entrevistá-lo uma primeira vez em Arinos, foi preciso também ir ao encontro de Dona Maria em um espaço coletivo reservado à atividade de ralar mandioca, localizado no bairro Crispim Santana, muito próximo à residência de sua família. A casa de Dona Maria, de outro modo, constituía espaço de feitura de artesanatos: local onde seu marido gasta tardes confeccionando peças e artefatos diversos com taboca. Fabrica principalmente cestos, com tabocas colhidas na "roça". Já Dona Maria se ocupa, simultaneamente, da arte de fazer tapetes de retalhos: em sua residência na cidade, ambas as artes são criadas hoje a partir de aprendizados e aperfeiçoamentos desenvolvidos na época em que residiam e trabalhavam na "roça". 
De modo não muito diferente, Lauro sempre buscou mostrar seus artesanatos nas ocasiões em que visitei sua residência, confeccionados com retalhos de madeira. Em geral, tratava-se de brinquedos para crianças, cujas técnicas de construção e valores associados seguiam princípios adquiridos na "roça" já havia muitos anos. Acessar esses contadores de histórias de vida, então, foi o mesmo que deparar-me, em parte, com aquele cotidiano. Não apenas pelo conteúdo das falas, mas pela qualidade das práticas observadas, nestes casos dispostas no campo artístico-cultural. Desta feita, os modos praticados na "roça"- em grande medida desenvolvidos em contextos onde a compra de artefatos diversos (roupas, brinquedos, enfeites, tecidos em geral, etc.) não era sempre possível, seja pelas distâncias a serem transpostas e/ou logística complexa necessária à obtenção, seja pelo modo de vida relativamente descapitalizado - compõem parte da vida cotidiana da cidade.

"Pode-se mesmo aventar a hipótese de que, em muitos casos, o morador do campo, que se transfere para a sede municipal, não muda, necessariamente de 'lugar', do ponto de vista sociológico, isto é, ele pode continuar integrando o mesmo mundo restrito de relações de interconhecimento. Com efeito, a sociedade rural não se esgota no pequeno espaço propriamente rural, mas se espalha pelas pequenas cidades que não só lhe servem de apoio político-institucional, como também constituem um quadro complementar de vida" (Wanderley 2004: 93).

O que diz Wanderley, acima, adquire, porém, outro significado, no sentido de que o observado em Arinos não aparece exatamente como "um quadro complementar". Dadas as distâncias, a irregularidade dos transportes e a dificuldade de se acessar as redes de interconhecimento estabelecidas na "roça", muitas vezes, o quadro complementar é apresentado mesmo como um novo quadro, do ponto de vista espacial e relacional. Se as redes de interconhecimento estabelecidas na "roça" não mais puderam ser facilmente acessadas, novas redes foram tecidas, em interação com outros moradores da cidade - interação agora mediada por um conjunto de valores ampliado, incluindo aqueles usados para desenhar imagens pejorativas daqueles que chegam da "roça". Também, considerando agora a cidade grande, adentramos, inevitavelmente, a questão da transmutação do sertão ("roça") às capitais (Melo 2011), ocupando suas periferias e favelas. Ou seja, nesses casos, modos "da roça" são alocados significativamente no espaço tido como urbano, de modo a compor a capital. Nesses espaços "metropolitanos", os residentes encerram por assumir postos de trabalho tidos como subalternos (também porque assumem apenas estes postos e não outros). Nessa perspectiva, tanto nas capitais quanto nas pequenas sedes municipais, foram percebidos períodos tidos pelos contadores como discriminatórios (figura 3). A problemática iniciava-se ainda na "roça", 
quando, momentos antes da mudança, a preocupação com as vestes a serem mostradas na cidade ficava eminente (Dona Maria; Joaquina).

"Mas o povo aqui [Arinos] era ingrato demais, meu filho... De primêro, o povo aqui era ruim, eles num dava hora pra pobre não, aqui era carrasco. Hoje? Hoje eu vô falá procê que mudô cento porcento, que hoje as pessoa, hoje os rico vê a gente, né, e dá mais atenção pro pobre, né, mas de premero..." [Dona Laurinda].

Essas informações, entre outras, suscitam a circulação de imagens negativas daqueles que chegavam da "roça", inclusive entre os próprios familiares e conhecidos já estabelecidos nas cidades (figura 4), como foi o caso de Joaquina, entre tantos outros:

"Aí, veio uma senhora fortona, era a mãe dele [do rapaz de Arinos que pretendia namorá-la], ela é morena igual eu, mas ela parece que achava que ela era branca. Ela chegou ni mim e falou assim: 'Ô sua traíra preta, eu quero que ocê volta do mesmo lugar que você saiu, não quero você perto do meu filho'. E ela nem me conhecia. Ela conhecia minha vó, que ela era vizinha da minha vó" [Joaquina].

Nos dias atuais, passadas décadas da primeira tentativa de mudança à cidade, a situação já não é mais a mesma. A condição de vida na sede municipal de Arinos é percebida não sem "tédio" e "perigo", mas com determinadas amenidades, tais como os acessos facilitados aos sistemas de saúde e educação. A antiga autossuficiência da "roça", à luz do processo de expansão da industrialização e do capitalismo modernos, e da nova configuração de divisão do trabalho, foi substituída pelas compras, nas quais, no caso dos mais velhos, figuram significativamente as aposentadorias. De fato, não há mais a necessidade de se torrar café, pilar arroz, ralar mandioca no ralo manual ou "pegar água na lata". Segundo os mais velhos, até as possibilidades de se estabelecer relações sexuais e/ou amorosas ficaram facilitadas aos jovens.

\section{DO TRÂNSITO AO RECENTE CAMPO ARTÍSTICO-CULTURAL}

A apreensão das características do trânsito - palavra que uso para representar o processo de "movimento" por dentro da dinâmica migratória - pode ser feita em entrelace com o entendimento da emergência de um campo artístico-cultural no território que circunda Arinos. A despeito das dificuldades vividas na "roça" e das restrições financeiras e distâncias físicas percebidas na cidade (em relação a ir até a "roça", revisitá-la), as épocas de folias constituíram, ininterruptamente, ocasiões de regresso às origens: uma peregrinação anual por meio 
da qual se podia empenhar uma espécie de atualização identitária; podiam-se reviver aqueles laços de solidariedade e relações de interconhecimento a que outrora os contadores flagraram-se acostumados. Dona Laurinda e Lauro, por exemplo, jamais deixaram de retornar às folias: são hoje, inclusive, "imperadora" e "imperador", respectivamente, de grupos de folia de Arinos. "Morei 28 anos em Brasília, mas nunca perdi uma folia” [Dona Laurinda]. Não raro, esses regressos compuseram eventos de investimentos afetivo-amorosos por parte dos que já viviam nas cidades e capitais. De modo geral, parte grande dos integrantes dos "ternos de folia" de Reis dali reside hoje em São Paulo, "Brasília", etc.

É a partir do acontecimento das folias, sejam estas realizadas na "roça" ou na cidade, que nos remetemos uma vez mais à ideia de territórios definidos segundo a categoria "movimento" (Cerqueira 2010; Andriolli 2011). Essa movimentação, particularmente aquela iniciada quando ocorria a mudança às sedes municipais, introduz-nos um importante paradoxo, que faz referência a questões identitárias, de pertencimento e de autoestima. Aquela cultura, à qual os "da roça" estavam visceralmente ligados, era a mesma cultura desvalorizada pelas mensagens hegemônicas que circulavam à época dos trânsitos às cidades e capitais, porque fora construída a imagem dos modos "da roça" como pertencentes a uma cultura menor, atrasada (Melo 2011; Wanderley 2004); atrelava-se esta cultura à imagem do subalterno, por sua vez projetada no seio da noção de desenvolvimento, que já tinha o fôlego de ideia-força; porém, era a mesma cultura à qual não se podia deixar de estar vinculado e que era atualizada com frequência, a exemplo do regresso anual às folias.

O paradoxo, no entanto, pareceu produzir reviravolta, especialmente desde 1997, data em que Seu Antônio Maria, participando de um dos encontros de folias de Reis na Granja do Torto (em "Brasília"), "descobriu" que o "São Gonçalo" - dança religiosa típica no território - era considerada como sendo "cultura". Até então, segundo ele, pensava-se que a dança só servia mesmo para pagar promessa. "Quem dança é para cumprir o voto, a promessa $[\ldots]$ hoje a cultura tá muito valorizada" [Seu Antônio Maria]. Dona Laurinda, coincidentemente, participara do mesmo encontro e dissera-me algo semelhante a Seu Antônio Maria. Segundo esses contadores, foi a partir daí que muitas pessoas de Arinos passaram a ter contato com a "cultura de tradição" - tida em sentido genérico como cultura popular - enquanto valor da "boa cultura", em sentido análogo a Canclini (201 1: 205-220), quando este retrata "a encenação do popular". Culminou que, particularmente desde o ano 2000, o "São Gonçalo" e as folias passaram a ser apresentados com maior intensidade, em ocasióes diversas, compondo festivais e encontros culturais da região (figura 6), mas não apenas. 


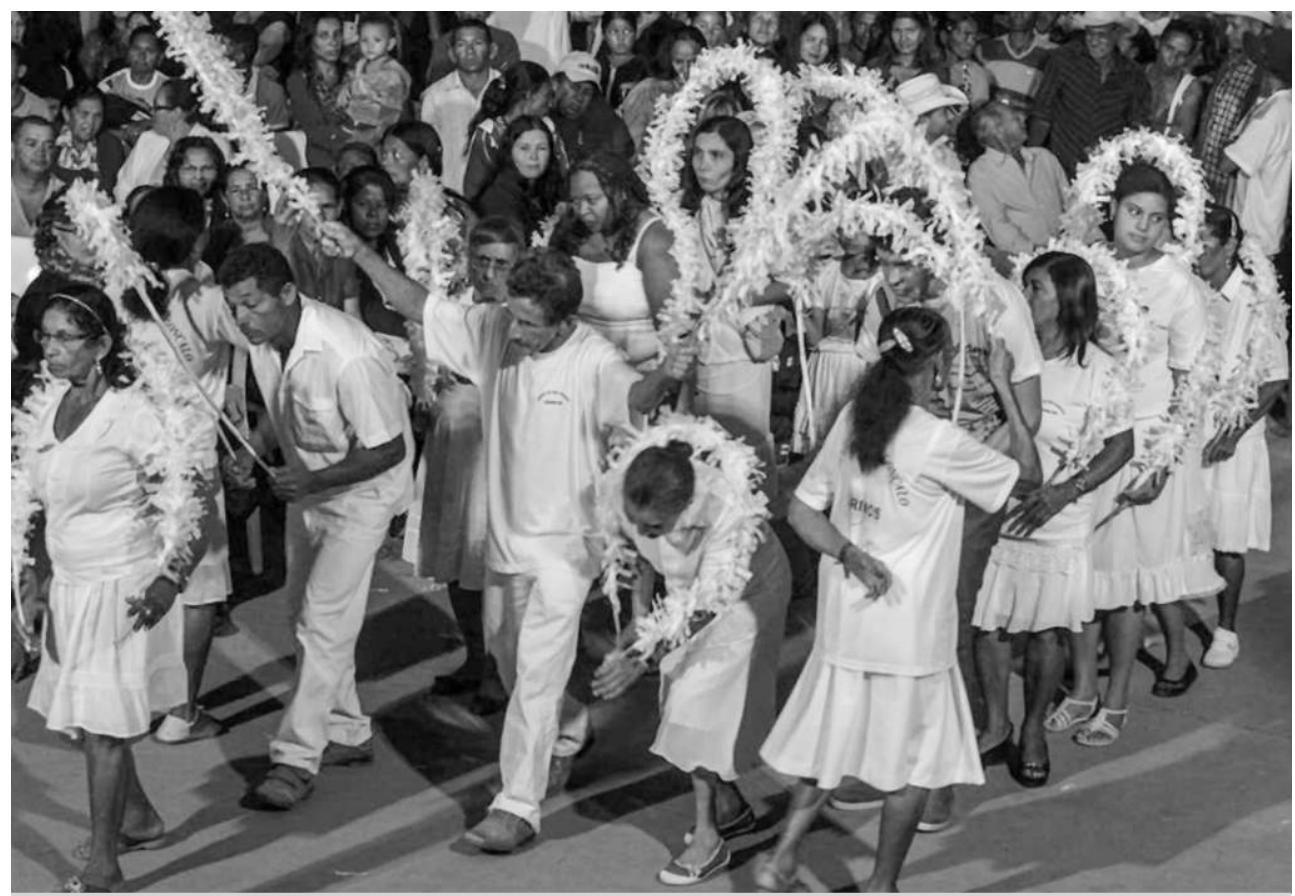

Figura 6 - Seu Antônio Maria, "guia de São Gonçalo", dançando no XII EPGSV, Chapada Gaúcha, 2013. Fonte: acervo do Instituto Rosa e Sertão; foto de Leo Lara, editada pelo autor.

Os principais eventos artístico-culturais de "cultura de tradição" da região - em que se apresentam agentes tais quais os contadores de histórias de vida e grupos de "cultura de tradição" em geral - são o Encontro dos Povos do Grande Sertão Veredas (EPGSV), de ocorrência anual em Chapada Gaúcha (vizinha a Arinos), e o Festival Sagarana, de ocorrência também anual em um distrito de Arinos. Estes encontros inscrevem-se no âmbito das ações daquela rede de atores contestatórios mencionada na primeira seção. De um modo geral, integram também o rol das ações dessa rede: a criação e execução de alguns "pontos de cultura"; 9 a condução de uma rede de produção e comercialização de "artesanato de tradição", em vários municípios próximos; a ocorrência anual de uma caminhada ecoliterária de 170 quilómetros, ligando o Festival Sagarana ao EPGSV, literalmente; a criação e manutenção de um Centro de Referência em Tecnologias Sociais do Sertão, onde se desdobram atividades relacionadas às agroflorestas, à produção de instrumentos musicais e de artesanatos, às bioconstruções e às práticas artístico-culturais; entre outras menos expressivas.

9 Grosso modo, os "pontos de cultura" correspondem a projetos artístico-culturais, com dotação financeira, propostos por organizações locais diversas (em geral ONGs e prefeituras), a partir de editais públicos federais e estaduais. 
Essa rede de atores contestatórios foi forjada ali a partir do ano 2000, por mediadores reconhecidos como atores da sociedade civil que, mantendo forte articulação interpessoal, deram início a essa série de iniciativas.

A relevância do EPGSV e do Festival Sagarana se dá, em grande medida, por razão de parte expressiva das disputas por ideias de desenvolvimento na região ser travada justamente no campo artístico-cultural. Ali as festas conformam espaços onde circulam signos do desenvolvimento, sejam aqueles vinculados ao modelo hegemônico - a partir dos quais se visa sustentar, por exemplo, a expansão da agricultura monocultural mecanizada - ou aqueles manejados para dar lastro a contratendências deste modelo. Inscritos em uma espécie de circuito regional de festas, que ocorre entre junho e setembro de cada ano, esses dois encontros fazem contraste simbólico com as demais festas desse circuito, porque valorizam a apresentação de grupos de "cultura de tradição", ou mesmo de artistas de maior renome que, de formas variadas, manejam referências dessa "cultura de tradição", como aquelas relacionadas às folias de Reis. Já as demais festas do circuito são marcadas por signos da cultura de massas ${ }^{10}$ e da agricultura modernizada voltada à produção de commodities, assim como pela operação de discursos populistas, a partir dos quais agentes políticos locais buscam o controle de poderes administrativos (cf. Chaves 2003).

Também, de modo emblemático, em meados da década de 2000, surge o "Idade de Ouro" (figuras 1, 4 e 5), programa social da administração pública de Arinos, coordenado pela Secretaria Municipal de Desenvolvimento Social. Surge voltado aos idosos e calcado na ideia de "resgate" da cultura tradicional local, expressa pelas danças, particularmente as de roda. Tal ideia ascende à pauta das ações locais sob influência indireta e respaldo de uma rede de atores sociais contestatórios, assim como foi dito na seção inicial. A criação da Secretaria Municipal de Cultura de Arinos em 2012, segundo o prefeito que a criou, teria sido, inclusive, consequência do sucesso desse programa junto aos idosos e à comunidade arinense. O "Idade de Ouro", do qual participam Dona Laurinda, Dona Maria e Seu Antônio Maria, é colocado em evidência como signo de uma espécie de regresso temporal - de retomada de uma "cultura de tradição" - que outrora fora significado enquanto trânsito. Nesse sentido, essas manifestações, as "danças de roda", aparecem como sendo do passado, menos porque deixaram de ocorrer e foram retomadas, e mais porque foram, em determinado momento, iluminadas segundo novos valores. Evidentemente, que, no caso das "danças de roda" manejadas para cortejo em ambiente regrado pelos

10 Neste caso, refiro-me aos chamados "grandes shows sertanejos", aos "forrós", aos "arrochas", entre outras modalidades, com artistas do circuito comercial de música, amplamente conhecidos e representantes do mainstream artístico-cultural. De outro modo, faz-se referência ao que é tomado por muitos como "balada". Neste caso, "balada" corresponde a à associação entre o consumo banalizado de bebidas alcoólicas, os shows de artistas excessivamente midiatizados (em muitos casos contendo músicas cujas letras são sexualizadas), o alto volume sonoro e a presença predominante de jovens. 
olhares atentos do pai, caíram mesmo em desuso. Figura, então, algo análogo ao encontro de valores apontados por Leal:

“Tão comum que aos olhos da própria comunidade aquele é um momento de festa e de confraternização junto aos seus, fazendo parte não de calendários de manifestações, mas do calendário da vida social e simbólica do lugar. Isso, até que alguém, um forasteiro, 'o de longe', ou 'o de fora da comunidade' reconheça na festa um evento folclórico, ou mesmo turístico, e o aponte como algo dotado de um outro significado, de um outro valor, diferentes de algo antes simbolicamente representativo daquele povo, daquele local" (2011: 37).

Desta feita, vidas que estiveram recheadas de dificuldades - a saída das "roças", o estranhamento das pequenas sedes municipais, a vivência da distinção social radicalizada à luz do individualismo urbano - são consagradas, em outro momento, a partir do reconhecimento de uma "cultura de tradição". Então, se parte das dificuldades da vida fora pelo pertencimento a uma "cultura" filtrada tácita e pejorativamente por muitos - a própria posição social relativa ocupada nas cidades e capitais revelava isso -, o reconhecimento dessa "cultura", simbolicamente, acessa uma dimensão que vai além da espetacularização sustentada segundo valores externos, conforme a perspectiva de Leal (2011). ${ }^{11}$ A saída das "roças" - um evento massivo e duradouro - ergue-se como elemento central para este entendimento. Mais ainda, compõe a memória coletiva local como uma espécie de trauma que se mostra às vezes consciente, ora inconsciente. Em última instância, um "trauma cultural".

Em ocorrendo a espetacularização no território, o que parece diferir de Leal é sua qualidade no que se refere a "quem reconhece" e "para quem se mostra" a manifestação cultural. À espetacularização são atribuídos significados diversos ali, para além da exibição voltada aos "de fora", como enfatizou Leal. Uma primeira forma de reconhecimento é aquela mediada pelo Estado, por meio das políticas culturais contemporâneas, que vêm sendo empregadas de forma inédita ali. ${ }^{12}$ No plano local, esse reconhecimento liga atores sociais, propaga uma imagem positiva acerca da "cultura de tradição", viabiliza a existência e circulação de "grupos culturais" constituídos e encerra por atrair muitos admi-

11 Espetacularização se refere à noção segundo a qual manifestações populares ditas tradicionais, apoiadas em modos de vida peculiares, são empenhadas no campo artístico-cultural destituídas das condições necessárias à reprodução social dos referidos modos de vida.

12 Nesse sentido, é relevante apontar alguns signos dessas políticas na região, quais sejam: a implantação recente de sistemas municipais de patrimônio cultural; a ocorrência de alguns pontos de cultura; a ocorrência anual de alguns festivais de "cultura de tradição" produzidos por organizações da sociedade civil; o funcionamento de uma rede de produção e comercialização de "artesanato de tradição", entre outros. 
radores. Diversos são os mecanismos públicos que conferem reconhecimento às manifestações. Uma segunda forma, de origem mais endógena, corresponde aos encontros de "cultura de tradição" (como o EPGSV e o Festival Sagarana). A partir destes, em alguma medida, se viabiliza a valorização por parte dos "de fora", porque é acionada uma rede maior de atores reconhecidos como movimentos sociais, além de, igualmente, se atrair público diversificado. Mas esses encontros geram também reconhecimento por parte dos "de dentro", porque os manifestantes veem-se homenageados por atores locais - e reforçam com eles laços de afetividade -, em especial aqueles ligados à rede local de atores contestatórios mencionada no início, que, por sua vez, acaba requerendo intensa interlocução com os "grupos culturais". Ainda, uma terceira forma é "local-regional", cristalizada na inserção de apresentações de "cultura de tradição” em eventos corriqueiros, em Arinos e em cidades próximas, que extrapolam os encontros de "cultura de tradição".

No cotidiano da sede municipal de Arinos, aqueles que compõem os grupos de "cultura de tradição", tais quais os narradores de história de vida, apresentam-se publicamente em ocasiões diversas proporcionadas pela prefeitura. Viajam regionalmente inclusive a expensas de recursos municipais (transporte e alimentação). Assim, é possível flagrar funcionários da prefeitura demandando com frequência a apresentação do grupo de "danças de roda" do "Idade de Ouro". Em Chapada Gaúcha, cidade vizinha, algo semelhante pode ser observado em relação ao grupo Manzuá (da Comunidade dos Bois), entre outros. Poder-se-ia expandir esses exemplos a outros municípios da região, ou ao grupo de fiandeiras de vários municípios que exibe a arte de fiar cantando (remontando à vida da "roça"). É dessa forma que aparece um significativo mercado cultural cogerido por ex-residentes da "roça", a exemplo de Seu Antônio Maria, Lauro e Dona Laurinda, e por membros das prefeituras, em particular a de Arinos. Classifico-o como significativo porque existe a oferta de grupos interessados em realizar apresentações, ao passo que a demanda por apresentá-los é posta à mesa das negociações. Esse mercado, no entanto, se mostra invisibilizado enquanto tal, a despeito das trocas e fluxos existentes; apesar disso, a demanda da prefeitura é intensa e expressa na forma de solicitações de apresentações. Mas ele emerge porque, em paralelo, os "fazedores de cultura" que vieram da "roça" e que acumulam já certa idade colocam-se como gestores culturais locais. ${ }^{13}$ Se "dançadoras" e "dançadores", "jogadores de verso" e "foliões" apreciam e esforçam-se para dar seguimento ao modo "apresentar-se" - em contraste aos modos "paquerar", "prestar homenagem religiosa", "comemorar o trabalho realizado" e "farrear" -, ao fazerem essas apresentações engajam-se enquanto organizadores, mobilizadores, articuladores e, até,

13 O termo "fazedores de cultura" foi apresentado como nativo. Entretanto, identifica-se a adoção do termo como tendo sido influenciada pelos jargões das políticas culturais contemporâneas. 
financiadores do processo, muito além de estarem restritos às apresentações propriamente ditas.

“É uma dificulidade pra gente ir [ao EPGSV], aconteceu, tem vez, da gente querer ir nalgum lugar, não poder ir porque a prefeitura não dá suporte $[\ldots]$ Agora nos derradeiro ano [...] de casa aberta, nos dois últimos anos é que ele [o prefeito] tava dando mais um suporte pra cultura" [Seu Antônio Maria].

A fala de Seu Antônio é emblemática para elucidar a relação dos grupos de "cultura de tradição" com a prefeitura. E nos introduz, sob outro ponto de vista, a interface que há entre as manifestações de "cultura de tradição", a gestão cultural realizada pelos "fazedores de cultura" e sua participação política no plano local. Porque as apresentações do cotidiano fazem estreitar os vínculos entre esses "fazedores" e a prefeitura, algo que passa a dar lastro para que sejam formuladas críticas e posições condizentes à forma de atuação desta última - forma intermitente, ressalta-se, cambiante e dependente das arbitrariedades políticas que se atualizam a cada exercício eleitoral -, particularmente em relação ao campo artístico-cultural. Nesse sentido, a gestão cultural por parte desses agentes compõe-se da organização dos "grupos culturais", da realização das apresentações, da articulação com a prefeitura, da interlocução com a mencionada rede de atores contestatórios e com organizadores dos eventos diversos, da logística de transporte, alimentação e hospedagem e, até, de enfrentamentos, a partir dos quais se busca colocar em pauta as percepções e demandas acerca do "sistema de troca" estabelecido com a prefeitura, tido ainda como assimétrico. Finalmente, o comando da reprodução social das manifestações tradicionais compõe o processo de gestão cultural local, algo que aparece tacitamente percebido como essencial: "Já ensinei vários aqui em Arinos. Uma dessas pessoa é o [Lauro]... Carlim, Chiquim, Fabrício e Cidi...” [Seu Antônio Maria].

Da saída da "roça" e de seu trânsito decorrente até a intensificação da espetacularização, que pode ser vista em grande medida como voltada para os "de dentro", parece ter sido formulado um tipo de demanda pela exposição da própria cultura, que fora sufocada no tempo e no espaço. Poder-se-ia chamar este fenômeno de "demanda identitária"? A própria relocalização dos modos da "roça", na cidade, teria deixado latentes os modos que hoje tanto soam como sendo do passado - mesmo porque até as "roças" já não são mais as mesmas; nelas tão facilmente não se vê mais os "forrozinhos" e as "danças de roda"; se, por um lado, as manifestações na "roça" diminuíram em frequência, por outro cederam espaço a novos elementos artístico-culturais, como aqueles advindos da cultura de massas. Observa-se, nesse contexto, a recrudescência das manifestações (figura 7), agora na cidade, algo que parece receber influência das ações da rede local de atores contestatórios, das políticas culturais que 
incorporaram novos valores subjacentes à tradição e, enfim, do conjunto de ações que se dão no âmbito da administração municipal. A "cultura de tradição" passa a ser objeto de múltiplos interesses: artístico-culturais, econômicos, simbólicos, identitários e turísticos, que se apoiam no reposicionamento de valores e dão vestígios da possibilidade - e apenas isto - de inversão de tendências, tal como aquela da "dominação da cultura de massas". Curioso notar que, tanto essa cultura de massas, quanto a visão pejorativa sobre os modos rurais, quanto a valorização da tradição (expressa inclusive em termos políticos) compõem a modernidade que aparece ali em termos contraditórios.

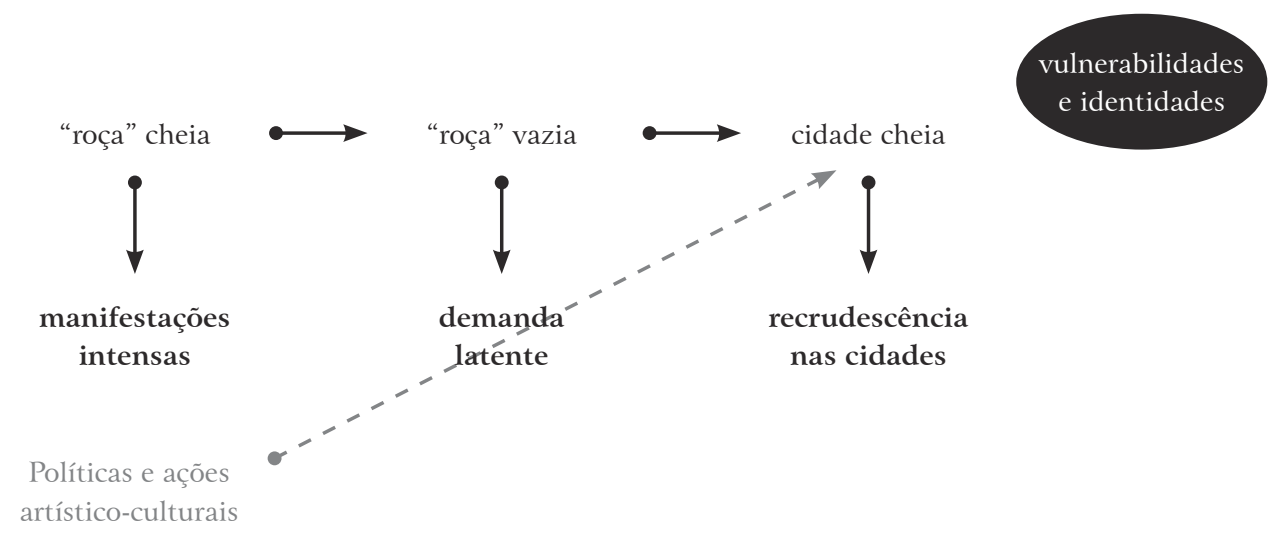

Figura 7 - Representação da dinâmica de manifestações tradicionais nos municípios de Arinos e Chapada Gaúcha, resultante do trânsito entre "roça" e cidade nas últimas décadas. Fonte: elaborada pelo autor.

\section{IMAGENS SOBRE O MUNDO RURAL E DESENVOLVIMENTO}

As disputas locais "de desenvolvimento" conformam um campo de representações (incluindo as imagens do rural) que acaba por expressar valores, conhecimentos, visões de mundo e realidades distintas. Nesse sentido, o EPGSV e o Festival Sagarana opõem-se às demais festas da região pela movimentação de outra pauta política, de cunhos ambiental, artístico-cultural e agrário (no sentido distributivo da terra), entre outros. Em um plano geral, identificam-se os contadores de histórias de vida compondo uma rede de atores contestatórios que questiona, de formas variadas, o modelo de desenvolvimento em curso, não sem contradições internas. Algo de particular dessa rede é a habilidade de seus agentes em tecer alianças, quais sejam: com os "de fora", em geral agentes afetos à "cultura de tradição" residentes nas capitais; com Deus e os signos do catolicismo; com grupos tidos como minorias (comunidades denominadas 
quilombolas, grupos indígenas, etc.); o Estado; e, particularmente, com representantes de comunidades variadas da "roça" (ou a "aliança com a tradição"); entre outros. Essas alianças correm em paralelo a processos continuados de construção de afinidades nos quais opera, marcadamente, a apropriação diferenciada da história local, em contraste com a história hegemônica (cf. PMCG 2012), que tende a invisibilizar a vida nativa precedente. A história alternativa que se tenta construir identifica a relação positiva com o cerrado, valoriza aspectos diversos dos modos de vida, da ocupação do espaço e das manifestações artístico-culturais intimamente ligadas a esses modos. Dessa forma, elementos das histórias de vida da "roça" - estejam estes em seu espaço original ou deslocados, nas cidades -, associados a outros corpos de conhecimento advindos, por exemplo, de mensagens das recentes políticas públicas culturais e ambientais, da literatura regionalista de João Guimarães Rosa, dos discursos de movimentos ambientalistas e de luta pela terra -, dão os contornos de um idioma de desenvolvimento (Haan e Long 1997; Arce e Long 2000; Ribeiro 2008) amalgamado. De formas variadas, busca-se, por meio desse idioma, desestabilizar no plano local o que Foucault (1984: 11) chama de "economia política da verdade", projetando-se o esboço de um regime de verdade concorrente.

Seguindo Carneiro (2012: 247-254), estaríamos a falar da flexibilidade social manifesta por ex-residentes da "roça" frente à dinâmica da modernidade. Ela aparece, então, como consequência (e sinônimo) das situações de vulnerabilidade vividas na cidade (figura 7) e resulta em imagens sobre o mundo rural que são produzidas acessando-se o campo artístico-cultural. A "roça", nesse sentido, passa a ser vista como um verdadeiro reservatório de "cultura", como se os símbolos que sustentavam um passado recente fossem hoje valorizados, consumidos e, sobretudo, utilizados na formulação de estratégias particulares: em última instância, estratégias de desenvolvimento de atores ligados ou imersos na "cultura de tradição". Isto nos remete a Cunha (2009: 354-363), quando esta trata a cultura também como via de elaboração de projetos políticos; daí que se observa que a coexistência entre cultura (sem aspas) e "cultura" (como recurso para afirmar identidade, dignidade e poder diante de regimes maiores) gera efeitos específicos. Assim, a "cultura de tradição" inscreve-se também nos marcos de uma "cultura com aspas", segundo a qual, havendo um jogo político de magnitude interétnica, a cultura é posicionada diferentemente conforme convenha ou seja possível.

A dita flexibilidade, de que trata Carneiro (2012), recai sobre o processo que dá vida às manifestações, ou seja, sob determinada perspectiva, a forma de fazê-las é que poderia ser dita flexível. O campo das manifestações da "cultura de tradição" não é estático, é dinâmico e está amparado em um conjunto maior de valores que vai além daquele que justifica sua existência original. Desta feita, podemos observar outras razões sustentando uma retomada da tradição, 
tais como as possibilidades de construções identitárias, de pertencimento, de autoestima e de cidadania. Este processo parece ter sido iniciado quando da percepção da circulação de valores que confrontam a imagem estigmatizada dos da "roça"; algo que estaria inscrito dentro do "campo de possibilidades" de que trata Carneiro (2012), apesar de que, aqui, este campo não seria definido exatamente pela "combinação das condições socioeconômicas e fatores peculiares às unidades familiares" (2012: 250), mas com forte influência das políticas e ações artístico-culturais, algo elucidado na figura 7. É nesse sentido que a ligação desses agentes da "roça" com a rede de atores contestatórios que age no território deve ser apreendida. Porque essa rede, por meio de linguagem própria, apoiada na releitura da história, na literatura regionalista, entre outros elementos, conecta modalidades artístico-culturais - o "artesanato de tradição", o turismo, os encontros de "cultura de tradição" -, de modo a dar corpo e consistência a uma experiência de desenvolvimento amparada em signos da "roça".

A questão da ruralidade aproxima-se do debate do desenvolvimento quando noções de rural são projetadas como imagens e representadas diferentemente por atores sociais diversos, algo que confere significado peculiar à interação entre estes (Haan e Long 1997; Carneiro 2012). As histórias de vida de ex-residentes da "roça" revelam um avanço para o campo das representações que coincide com o "campo das possibilidades". Estas representações carregam consigo um universo simbólico e uma visão de mundo que lhes correspondem e que, sendo plurais, exprimem formas múltiplas de se afiliar ao território (Froehlich 2003). A imagem do rural - do desenvolvimento rural, em última instância está em jogo e se torna objeto de disputa em uma arena onde passam a figurar - ou, se não passam, figuram com expressão renovada - agentes que se colocam enquanto "fazedores de cultura" e, de modo quase inevitável, aceitam a mediação de entes com os quais compartilham valores "contestatórios".

"Como sustentamos, a ruralidade não é mais possível de ser definida com base na oposição à urbanidade. O rural e o urbano corresponderiam, portanto, a representações sociais sujeitas a reelaborações e ressemantizações diversas de acordo com o universo simbólico a que estão referidas. A ruralidade se expressa de diferentes maneiras como representação social - conjunto de categorias referidas a um universo simbólico ou visão de mundo - que orienta práticas sociais distintas em universos culturais heterogêneos, num processo de integração plural com a economia e a sociedade urbano-industrial" (Carneiro 1998: 73).

Observa-se, assim, a (re)construção identitária por parte de agentes que estabelecem relações sociais específicas e, não raro, trançam coalizões - os da "roça" e agentes contestatórios - para interagir em arenas de domínios discursivos e de representação concorrentes. Esse seria um dos significados locais do 
rural - da "roça" - enquanto espaço heterogêneo, sobretudo no que tange as representações sociais. Nesse sentido, uma visão de mundo oposta à "cultura de tradição" pode ser representada pela agricultura tecnificada, por meio da qual foi possível transformar antigas áreas de "gerais" - áreas de cerrado, de "roça", no final das contas - em campos de monocultura, hoje vistos como signo de desenvolvimento. Muitos foram os habitantes de Arinos que referenciaram a cidade vizinha Chapada Gaúcha ${ }^{14}$ como um pólo de monoculturas tecnificadas, como espaço de progresso, emprego e desenvolvimento, assim como observou Chaves (2003) em relação ao município de Buritis ali próximo. Essa imagem do rural, dominado pela técnica, chega a ser propagandeada pela prefeitura de Chapada Gaúcha (figura 8). Nesse sentido, frisa-se, a figura 8, em termos de imagem de desenvolvimento projetada, é concorrente da figura 6, a partir da qual tem-se que o desenvolvimento é artístico-cultural. Considerando as práticas discursivas em jogo, observa-se contradição quando se verifica parte expressiva da população de Chapada Gaúcha vestindo camisetas que remetem às diversas edições do EPGSV, por sua vez espaços de oposição explícita ao modelo de agricultura conduzido no território.

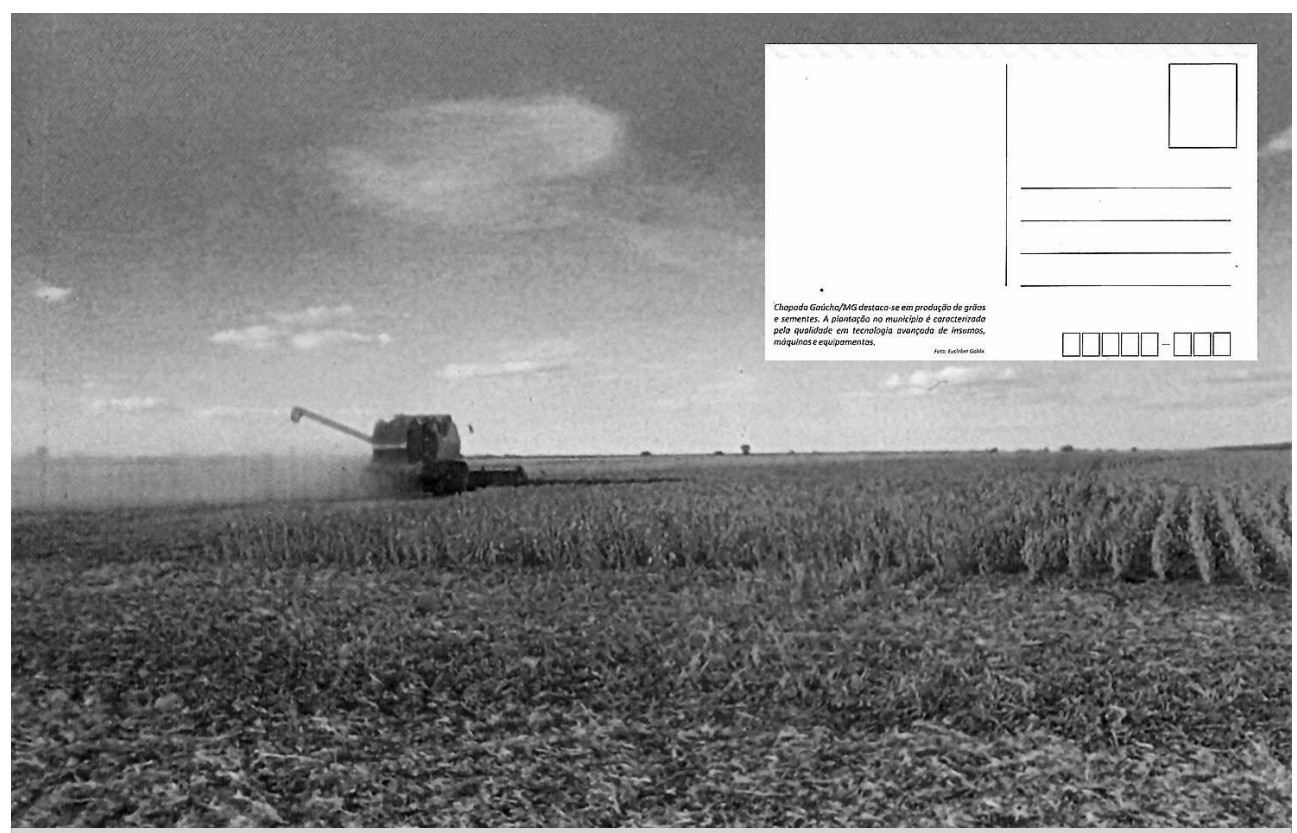

Figura 8 - Cartão postal de Chapada Gaúcha, distribuído pela prefeitura a eventuais visitantes em 2013 (frase do verso: "Chapada Gaúcha/MG destaca-se em produção de grãos e sementes. A plantação no município é caracterizada pela qualidade em tecnologia avançada de insumos, máquinas e equipamentos").

Fonte: Foto de Eucleber Gobbi, editada pelo autor.

14 Aqui, Chapada Gaúcha deve ser compreendida compartilhando um território com Arinos. 
Se a "retomada identitária" embasada nas histórias vividas participa na projeção de imagens plurais sobre o rural - não tanto pela pluriatividade laboral, mas mais pelas representações e formas de afiliação ao território -, esse processo é revelado, com grande força, agora na cidade, a despeito da oposição entre "cidade" e "rural" comumente observada. A cidade é constituída enquanto espaço de disputa de visões de mundo e de representações: enquanto o papel que lhe é atribuído por parte dos atores sociais não pode ser desprezado, a reprodução e ressignificação de valores (como o da boa "cultura de tradição") dá-se na interação entre esses atores e outros agentes. Trata-se de uma das formas encontradas para realizar agência (Long 2007), de modo tal que a questão do desenvolvimento é deslocada, sorrateiramente, para o campo simbólico, por mais que se possam identificar, no plano discursivo da mediação, questões econômicas associadas (o "artesanato de tradição", o turismo, etc.). São as cidades, em grande medida, os espaços desses símbolos, que são colocados como rurais ("da roça”), ao menos no que se refere ao seu uso estratégico para a mudança social e as construções que lhe correspondem.

Em termos objetivos imediatos, essa dinâmica aponta para a criação de novos espaços de sociabilidade - a exemplo do "Idade de Ouro" e do EPGSV e acaba por tangenciar o campo da economia, como o turismo e o artesanato, conferindo algum fôlego a uma cultura que amargou com a distinção social radical e crônica. Também o reconhecimento perante a própria comunidade parece estar permitindo o reposicionamento gradual das pessoas ligadas à "roça". Destaca-se, nesse sentido, o reconhecimento por parte do poder público municipal, que aponta para a institucionalização de processos relevantes à condução do "projeto local". Dos contadores de histórias de vida extrai-se que as danças tradicionais vêm sendo operadas como veículo de coesão de grupo, e a intermitência desse tipo de interação social constitui marca profunda que lhes impõe desafios pessoais e coletivos para os quais ainda se busca resolução. Conseguem, então, gradativamente, ao que parece, margem de manobra importante para firmar valores no plano de um coletivo local mais abrangente (o "Idade de Ouro", a rede de "artesanato de tradição", os encontros de "cultura de tradição", etc.), apesar das fragilidades institucionais que se mostram. Ao mesmo tempo, alguns espaços já instituídos permitem o encontro de grupos de origem comum, "da roça".

A dimensão social da espetaculariazação é convertida, sob o ponto de vista desses agentes "fazedores de cultura", em uma experiência de desenvolvimento "exitosa", sem dispensar as contradições e ambiguidades que estão em cena. Nos dias atuais, é por meio do campo artístico-cultural, particularmente, que os "da roça" têm lidado com questões de alteridade ligadas à construção identitária. O efeito de desenvolvimento é reforçado quando se incorpora o fato de que a negação da própria cultura entre os mais jovens, em contexto de encontro de valores, aparece ainda com intensa força, dos pontos de vista histórico e psicológico. 


\section{BIBLIOGRAFIA}

ANDriolli, Carmen Silvia, 201 1, Sob as Vestes de Sertão Veredas, o Gerais: "Mexer com Criação" no Sertão do IBAMA. Campinas, Instituto de Filosofia e Ciências Humanas da Universidade Estadual de Campinas, tese de doutorado.

ARCE, Alberto, e Norman LONG (orgs.), 2000, Anthropology, Development and Modernities: Exploring Discourses, Counter-Tendencies and Violence. Londres, Routledge.

BOURDIEU, Pierre, 2006, "O camponês e seu corpo", Revista de Sociologia e Política, 26: 83-92. BRANDÃO, Carlos Rodrigues, 1999, O Afeto da Terra. Campinas, Editora da Unicamp.

CANCLINI, Néstor García, 201 1, Culturas Híbridas: Estratégias para Entrar e Sair da Modernidade. São Paulo, Editora da USP.

CARNEIRO, Maria José, 1998, "Ruralidade: novas identidades em construção", Estudos Sociedade e Agricultura, 11: 53-75.

CARNEIRO, Maria José (org.), 2012, Ruralidades Contemporâneas. Rio de Janeiro, Mauad X/ FAPERJ.

CARVAlHO, Horácio Martins de (org.), 2014, Chayanov e o Campesinato. São Paulo, Expressão Popular.

Cerqueira, Ana Carneiro, 2010, O "Povo" Parente dos Buracos: Mexida de Prosa e Cozinha no Cerrado Mineiro. Rio de Janeiro, Museu Nacional - Universidade Federal do Rio de Janeiro, tese de doutorado.

CHAVES, Christiane de Alencar, 2003, Festas da Política: Uma Etnografia da Modernidade no Sertão (Buritis - MG). Rio de Janeiro, Relume Dumará/Núcleo de Antropologia da Política da Universidade Federal do Rio de Janeiro.

CUNHA, Manuela Carneiro da, 2009, Cultura com Aspas e Outros Ensaios. São Paulo, Cosac Naify. DELGADO, Guilherme, 2005, “A questão agrária no Brasil, 1950-2003”, em Luciana Jaccoud (org.), Questão Social e Políticas Sociais no Brasil Contemporâneo. Brasília, Instituto de Pesquisa Econômica Aplicada, 51-90.

DURKHeIM, Émile, 2015, Da Divisão Social do Trabalho. São Paulo, Edipro.

ESCOBAR, Arturo, 2005, “El 'postdesarrollo' como concepto y práctica social”, em Daniel Mato (org.), Políticas de Economía, Ambiente y Sociedad en Tiempos de Globalización. Caracas, Universidad Central de Venezuela, 17-31.

FAUSTO, Boris, 2006, A História Concisa do Brasil. São Paulo, Editora da USP.

FOUCAUlT, Michel, 1984, Microfísica do Poder, Rio de Janeiro, Graal.

FROEHLICH, José Marcos, 2003, "A (re)construção de identidades e tradições: o rural como tema e cenário", Antropolitica, 14: 117-132.

GOFFMAN, Erving, 1989, A Representação do Eu na Vida Quotidiana, Petrópolis, Vozes.

HAAN, Henk de, e Norman LONG (orgs.), 1997, Images and Realities of Rural Life. Assen, Van Gorcum.

LEAL, Alessandra Fonseca, 201 1, Semear Cultura, Cultivar Culturas Populares, Colher Patrimônios: A Gestão Social da Cultura Popular às Margens do Rio São Francisco no Norte de Minas Gerais. Uberlândia, Instituto de Geografia da Universidade Federal de Uberlândia, dissertação de mestrado.

LONG, Norman, 2007, Sociología del Desarrollo: Una Perspectiva Centrada en el Actor. Cidade do México, Centro de Investigaciones y Estudios Superiores en Antropología Social.

MARTINS, José de Souza, 1991, Expropriação e Violência: A Questão Política no Campo. São Paulo, Hucitec. 
MARTINS, José de Souza, 1994, O Poder do Atraso: Ensaios de Sociologia da História Lenta. São Paulo, Hucitec.

MELO, Adriana Ferreira de, 2011, Sertões do Mundo: Uma Epistemologia. Belo Horizonte, Instituto de Geociências da Universidade Federal de Minas Gerais, tese de doutorado.

MENEGHEL, Stela Nazareth, 2007, "Histórias de vida: notas e reflexões de pesquisa", Althenea Digital, 12: 115-129.

MENEGHEL, Stela Nazareth, et al., 2008, "Histórias de dor e de vida: oficinas de contadores de histórias", Saúde e Sociedade, 17 (2): 220-228.

MEYER, Gustavo, Flávia Charão MARQUES, e Gabriel Túlio de Oliveira BARBOSA, 2016, "Entidades performáticas e desestabilização: o desenvolvimento local para além do mainstream", Interações (UCDB), 17 (1): 33-45.

MOreIRA, Daniel Augusto, 2002, O Método Fenomenológico na Pesquisa. São Paulo, Pioneira Thomson Learning.

PEIRANO, Marisa Gomes e Souza, 1997, "Antropologia política, ciência política e antropologia da política”, Série Antropologia (UnB), 231: 15-26.

PEREIRA, Luzimar Paulo, 2009, Os Giros do Sagrado: Um Estudo Etnográfico sobre as Folias em Urucuia - MG. Rio de Janeiro, Instituto de Filosofia e Ciências Sociais da Universidade Federal do Rio de Janeiro, tese de doutorado.

PMCG - Prefeitura Municipal de Chapada Gaúcha, 2012, A Saga dos Gaúchos no Sertão Norte Mineiro. Chapada Gaúcha-MG, Prefeitura Municipal de Chapada Gaúcha.

RIBEIRO, Gustavo Lins, 2008, "Poder, redes e ideologia no campo do desenvolvimento", Novos Estudos (CEBRAP), 80: 109-125.

SABOURIN, Eric, 2009, Camponeses do Brasil: Entre a Troca Mercantil e a Reciprocidade. Rio de Janeiro, Garamond Universitária.

SILVA, Manuel Carlos, 2012, Sócio-Antropologia Rural e Urbana: Fragmentos da Sociedade Portuguesa (1960-2010). Porto, Edições Afrontamento.

SIMMEL, Georg, 2006, Questões Fundamentais da Sociologia: Indivíduo e Sociedade. Rio de Janeiro, Jorge Zahar Editor.

SØNDERGAARD, Dorte Marie, 2002, "Poststructural approaches to empirical analysis", International Journal of Qualitative Studies in Education, 15 (2): 187-204.

SOUZA, Marcos Spagnuolo, 2000, Vidas Vividas em Arinos. Arinos, Agência de Desenvolvimento Integrado e Sustentável do Vale do Rio Urucuia.

TÖNNIES, Ferdinand, 1957, Community \& Society. Nova Iorque, Harper \& Row.

WANDERLEY, Maria de Nazareth Baudel, 2004, "Olhares sobre o rural brasileiro", Raizes, 23 (1): 82-98.

WANDERLEY, Maria de Nazareth Baudel, 2009, "O mundo rural brasileiro: acesso a bens e serviços e integração campo-cidade”, Estudo Sociedade e Agricultura, 17 (1): 60-85.

WEBER, Max, 1987, "Conceito e categorias da cidade”, em Otávio Velho (org.), O Fenômeno Urbano. Rio de Janeiro, Guanabara, 67-88.

WEBER, Max, 1994, Economia e Sociedade. Brasília, Editora da UnB.

WEISHEIMER, Nilson, 2005, "Jovens agricultores: gênero, trabalho e projetos profissionais", Anais do 29. Encontro Anual da ANPOCS, CD-ROM. 